\title{
The Trouble with All-or-Nothing Settlements
}

\author{
Howard M. Erichson ${ }^{*}$
}

\section{INTRODUCTION}

When defendants settle litigation involving multiple plaintiffs, they often insist that they will settle only if they obtain releases from all or nearly all of the plaintiffs in the group. If a defendant is going to spend money to resolve claims, it prefers to take its hit and move on. As one experienced settlement administrator puts it, when a defendant approaches plaintiffs' lawyers to discuss the settlement of a mass dispute, the "subject might be broached in various terms, [but] the underlying message is the same- 'How much will it cost us to get out of all of these cases?" "1 A settlement that leaves significant exposure-or worse, that invites new claimants to join the fray by displaying easy money-holds little appeal.

Judges, lawyers, and academics largely accept the drive for comprehensive settlements as a given, and many embrace such settlements as a positive goal. ${ }^{2}$ The Federal Judicial Center's Manual for Complex Litigation offers tips for judges on how to achieve global settlements. ${ }^{3}$ Multidistrict proceedings, the Manual explains, "afford a unique opportunity for the negotiation of a global settlement," and transferee judges should "make the most of this opportunity."

* Professor, Fordham Law School. My thanks to Laurence Abraham, Elizabeth Chamblee Burch, John Leubsdorf, Jacqueline Nolan-Haley, Russell Pearce, William Simon, and Benjamin Zipursky for their comments and assistance. By way of disclosure, I testified as an expert witness on behalf of the United States in the criminal trial arising out of the Kentucky fen-phen settlement, and I have advised lawyers in connection with settlements in the Baycol, ephedra, fen-phen, Ketek, OrthoEvra, Rezulin, Vioxx, and Zyprexa litigations.

1. Matthew L. Garretson, A Practical Approach to Avoiding Aggregate SETTLEMENT CONFLICTS, 2 (2004), http://www.settlementplan.com/pdf/aggregate_settlements.pdf; see also PAUl D. Rheingold, Litigating MASs TORT CASES $\S 14: 17$ (2009) ("Nothing is more natural than for the defendant in [a mass tort litigation] to want to offer an attorney who represents a number of plaintiffs a lump sum which will settle all the cases.").

2. See generally Howard M. Erichson \& Benjamin C. Zipursky, Consent versus Closure, 96 CORNELL L. REV. (forthcoming 2011) (addressing the demand for closure in mass tort settlements and criticizing the means by which closure has been sought).

3. See MANUAL FOR COMPLEX LitigAtion (FOURTH) $§ 20.132$ (2004).

4. Id. 
American Law Institute's 2010 Principles of the Law of Aggregate Litigation proposes significant legal reforms to facilitate both settlement class actions and all-or-nothing aggregate settlements. ${ }^{5}$ Academics describe global settlement as a value-generating enterprise and the natural endgame of mass litigation. ${ }^{6}$

All-or-nothing settlements, however, cause a lot of mischief. Instances of unethical and even criminal conduct by plaintiffs' lawyers may be traced to defendants' insistence on fully comprehensive deals. Although the demand for comprehensive settlements is driven primarily by defendants and their insurers, plaintiffs' lawyers bear the brunt of the problem because all-or-nothing settlements put plaintiffs' lawyers in an ethically shaky position. Over the past decade, a number of plaintiffs' attorneys have faced disciplinary proceedings, civil lawsuits, and criminal prosecutions for their conduct in connection with comprehensive settlements in mass litigation. Although it is tempting to put the blame on lawyers who engage in questionable conduct, it would be a mistake to attribute the problem entirely to individual venality or ignorance. The ethical problems with mass settlements are systemic and linked to defendants' demands for fully inclusive deals.

This symposium, looking at aggregate litigation since Amchem Products, Inc. v. Windsor ${ }^{7}$ and Ortiz v. Fibreboard Corp., ${ }^{8}$ offers a perfect opportunity to review the trouble caused by all-or-nothing settlements. Amchem and Ortiz represented a high-water mark in the search for comprehensive resolutions. Both of those asbestos settlement class actions were driven by defendants' insistence on inclusiveness and

5. A.L.I., Principles of the Law of AgGregate Litigation $\S \S 3.06,3.14,3.17$ (b) (2010) [hereinafter AGGREGATE LiTIGATION] (proposing that settlement class actions be certifiable even if they could not be certified for litigation, opposing collateral attacks on class settlements, and proposing that clients be permitted to give advance consent to aggregate settlements with a supermajority voting provision).

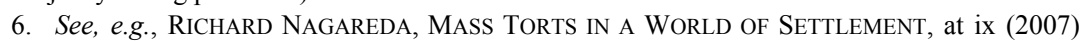
("As in traditional tort litigation, the endgame for a mass tort dispute is not trial but settlement. But the scope of the settlement differs. Here, the most ambitious settlements seek to make and enforce a grand, all-encompassing peace in the subject area of the litigation as a whole."); Samuel Issacharoff, Private Claims, Aggregate Rights, 2008 SUP. CT. REV. 183, 217 (2009) (describing the challenge of the Vioxx settlement as "how to create an effective bill of peace that would bring a reasonable (and reasonably certain) end to the litigation"); Edward F. Sherman, The MDL Model for Resolving Complex Litigation If a Class Action is Not Possible, 82 TUL. L. Rev. 2205, 2223 (2008) ("The MDL model, applied creatively, can be an effective alternative in certain situations to class treatment for accomplishing an aggregate or global settlement... [T] he model may include bellwether trials and a global settlement crafted cooperatively by counsel in both federal and state courts, and blessed and overseen in execution by the MDL court.").

7. 521 U.S. 591 (1997).

8. 527 U.S. 815 (1999). 
both were ultimately rejected for overreaching. ${ }^{9}$ The Amchem settlement arose out of the defendant asbestos consortium's refusal to settle individual claims unless the deal provided a global resolution. ${ }^{10}$ The Ortiz settlement went even further, seeking total resolution without any possibility of opt-outs. ${ }^{11}$ No procedural device outside of bankruptcy offers greater finality than the Rule 23(b)(1)(B) mandatory class action approach attempted in Ortiz. ${ }^{12}$ The no-opt-out course in Ortiz was driven by the defendant's primary liability insurer, which refused to participate in any settlement unless the settlement could guarantee "total peace."13 The Supreme Court rejected the aggressive use of Rule 23(b)(1)(B) in Ortiz, ${ }^{14}$ just as it had rejected the Rule 23(b)(3) settlement class action in Amchem. ${ }^{15}$ The hunger for comprehensive settlements, however, has not abated in the past decade. Rather, the field has shifted in part from Rule 23 settlement class actions to nonclass aggregate settlements.

In nonclass cases, defendants may pursue wholesale peace either globally or firm-by-firm. In some mass settlements, defendants seek to resolve an entire dispute and insist that the settlement include all or nearly all significant claimants. Working with leading plaintiffs' lawyers, defendants may negotiate a global settlement with provisions to ensure comprehensiveness. In other cases, defendants negotiate firm-byfirm settlements with plaintiffs' law firms that represent large numbers of claimants, insisting that each settlement include all of the firm's clients with claims against the defendant.

This Article employs a broad definition of "all-or-nothing settlements." It includes not only settlements with explicit clauses that condition the entire deal on full participation, but also settlements with other provisions that reveal an expectation of full participation or create pressure to bind every member of the claimant group. For example, it

9. See id. at 864-65; Amchem, 521 U.S. at 622-29.

10. The consortium of asbestos manufacturers, the Center for Claims Resolution (CCR), approached a group of leading asbestos plaintiffs' lawyers to negotiate a settlement but refused to settle individual asbestos claims unless the defendants could obtain a global resolution including future claims. Amchem, 521 U.S. at 600-01 ("CCR counsel approached the lawyers who had headed the Plaintiffs' Steering Committee... [and who] represented thousands of plaintiffs with thenpending asbestos-related claims... CCR indicated in these discussions that it would resist settlement of [those] cases absent 'some kind of protection for the future."')

11. See Ortiz, 527 U.S. at $825-26$.

12. Id. at $843,859-60$

13. See id. at 824 ("Because Continental conditioned its part in any settlement on a guarantee of 'total peace,' ensuring no unknown future liabilities, talks focused on the feasibility of a mandatory class action, one binding all potential plaintiffs and giving none of them any choice to opt out of the certified class.").

14. Id. at $864-65$.

15. Amchem, 521 U.S. at $622-25$. 
includes settlements that are not fully funded by the defendant until after the defendant receives releases from all of the claimants. It also includes settlements in which the plaintiffs' lawyers agree to be retained by the defendant upon the completion of the settlement, and those in which the plaintiffs' lawyers agree to withdraw from representing any clients who decline the settlement. The point of this Article is not to arrive at a precise definition of an all-or-nothing settlement, but rather to understand the ethical pressures created by various settlement structures that attempt to ensure full participation by a group of claimants.

This Article examines the ethical downside of all-or-nothing settlements. Part II tells the stories of lawyers who have faced trouble in recent years over their handling of such settlements. The stories reveal the opportunities and pressures created by defendants' insistence on bringing all claimants into a settlement. Part III catalogues the ethical problems created by demands for fully inclusive settlements. At least seven types of problems arise: (1) conflict of interest problems, (2) allocation problems, (3) the holdout problem, (4) the slush fund problem, (5) the loyalty problem, (6) the informed consent problem, and (7) the collusion problem.

Pointing out the trouble with all-or-nothing settlements does not mean that such settlements should never be allowed. Nor does it mean that comprehensiveness is an unworthy goal in mass dispute resolution. Defendants have good reason to seek peace, and inclusive settlements provide value for claimants as well as for defendants. ${ }^{16}$ Rather, this Article's catalogue of troubles suggests that the current love affair with global settlements - evident in academic writings, judicial pronouncements, and defendant demands - should be tempered by a realistic appreciation of the ethical downside.

\section{LAWYERS IN TROUBLE}

Aggregate settlements have led too many lawyers into trouble. The trouble ranges from public criticism, civil lawsuits, and disciplinary proceedings through felony prosecutions. ${ }^{17}$ Some have faced substantial

16. See NAGAREDA, supra note 6, at ix; Issacharoff, supra note 6, at 218-19.

17. Not all courts have come down hard on lawyers who failed to comply with ethics requirements in aggregate settlements. Particularly in cases involving advance consent, courts have steered clear of criticizing the lawyers, even as those courts have rejected settlements for noncompliance. In Hayes v. Eagle-Picher Industries, Inc., 513 F.2d 892, 894-95 (10th Cir. 1975), the court undid an all-or-nothing, lump-sum settlement because not all of the clients consented. Although the clients had agreed to be bound by a majority vote, the court held the arrangement illegal under the aggregate settlement rule. Id. at 894 . However, the court explicitly disavowed any 
punishment, but even lawyers who ultimately avoided sanctions or liability faced the burden and stigma that comes with defending themselves against charges of unethical conduct. To the extent these lawyers engaged in wrongful conduct, undoubtedly some of the blame can be laid on individual lawyers' greed or ignorance of ethical obligations. Any large pot of money can create temptation, just as any aggregate settlement can trip up unwary lawyers. An examination of these stories, however, suggests that the problem is not simply aggregate settlements, but settlements that push too hard to bring all claimants into the deal. The problems with such settlements reach well beyond the ordinary temptations of handling other people's money. While lawyers who act unethically are fully responsible for what they have done, it is worth stepping back to ask whether particular settlement structures are particularly likely to generate serious ethical problems. All-or-nothing settlements systematically and predictably create opportunities for abuse.

\section{A. The Kentucky Fen-Phen Settlement}

In 2009, attorneys William Gallion and Shirley Cunningham, Jr. were convicted of multiple counts of federal wire fraud and sentenced to twenty-five years and twenty years, respectively, for their handling of an aggregate settlement in the fen-phen diet drugs litigation. ${ }^{18}$ They were ordered, in addition, to pay over $\$ 127$ million in restitution, ${ }^{19}$ and both were permanently disbarred. $^{20}$ A colleague, Melbourne Mills, Jr.,

criticism of the plaintiffs' lawyer: "We are not to be understood as criticizing the professional conduct of the trial attorney for the appellants .... Undoubtedly plaintiffs'-appellants' attorney at the trial acted in good faith in handling a complex matter in which he was having to represent the interests of a number of clients." Id. at 895 n.3. In Knisley v. City of Jacksonville, 497 N.E.2d 883, 886-87 (Ill. App. Ct. 1986), the court reversed the enforcement of a settlement that had been approved by a majority of the client group, finding the majority-rule approach "completely at odds with our supreme court's Code of Professional Responsibility," but the court stopped short of criticizing the lawyer for his conduct. In Tax Authority, Inc. v. Jackson Hewitt, Inc., 898 A.2d 512, 522-24 (N.J. 2006), the court ultimately found a way to enforce the all-or-nothing settlement, despite the court's conclusion that the majority-rule settlement violated the rules of professional conduct. The court decided that its ruling would apply only prospectively, permitting enforcement of the settlement, in part because the court considered the lawyer blameless: "Plaintiffs' counsel represented plaintiffs that were from many different states and successfully sought to have all plaintiffs agree in advance to be bound by a weighted majority. That effort was a plausible, although incorrect, interpretation of [the rules of professional conduct]." Id. at 523.

18. Press Release, U.S. Attorney's Office, E. Dist. Ky., Fen-Phen Lawyers Sentenced for Wire Fraud \& Wire Fraud Conspiracy (Aug. 17, 2009), available at http://www.usdoj.gov/usao /kye/press/august/fenphen_sent.html.

19. Id.

20. Gallion v. Ky. Bar Ass'n, 266 S.W.3d 802, 807 (Ky. 2008); Cunningham v. Ky. Bar Ass'n, 266 S.W.3d 808, 813 (Ky. 2008). 
avoided criminal conviction but faced disciplinary sanctions. ${ }^{21}$ In a parallel civil proceeding, all three were found liable to their former clients for $\$ 42$ million. $^{22}$ The story of what these lawyers did wrong reveals some of the pressures and risks created when defendants demand that all claimants be included in a mass settlement.

Gallion, Cunningham and Mills had represented the plaintiff class in a Kentucky statewide fen-phen class action. ${ }^{23}$ After a separate nationwide settlement class action resolved many of the claims, what remained in the Kentucky class were approximately five hundred plaintiffs who had opted out of the nationwide settlement. ${ }^{24}$ The vast majority of these plaintiffs were clients of Gallion, Cunningham and Mills. ${ }^{25}$ The defendant, American Home Products (AHP, now Wyeth), approached the attorneys to negotiate a settlement for the claimants who had signed individual retainer agreements with these three attorneys. AHP agreed to pay $\$ 200$ million to settle the claims of the attorneys' fenphen clients. $^{26}$ The settlement of the 440 individual claims was conditioned on decertification of the Kentucky class action. ${ }^{27}$

21. Mills was indicted along with Gallion and Cunningham but was acquitted on the grounds that he had been too drunk to form the requisite criminal intent. See Debra Cassens Weiss, Jury Acquits Fen-Phen Lawyer Who Used Drinking Defense in Fraud Case, ABA JouRnal OnLINE, July 1 , 2008, http://www.abajournal.com/news/jury_acquits_fen_phen_lawyer_mills_of_defrauding clients. Gallion and Cunningham were convicted in a subsequent retrial without Mills. See supra note 18 and accompanying text. Mills was suspended from practice in 2006 . Inquiry Comm'n v. Mills, 203 S.W.3d 130, 130 (Ky. 2006). In 2009, a hearing officer recommended that Mills be permanently disbarred. See Andrew Wolfson, Permanent Disbarment Recommended for Fen-Phen Lawyer Mills, COURIER-JouRnAL (Louisville, Ky.), Sept. 28, 2009, at A1.

22. Andrew Wolfson, Attorney Toppled Diet-Drug Case Goliaths, COURIER-JournaL (Louisville, Ky.), Sept. 8, 2009, at A1.

23. Cunningham, 266 S.W. 3d at 808-09.

24. Press Release, supra note 18.

25. $I d$.

26. Letter Agreement from American Home Products to William Gallion et al., Settling Attorneys (May 1, 2001), available at http://news.cincinnati.com/includes/sections/fen/fen1.pdf [hereinafter Kentucky Fen-Phen Settlement Agreement] ("In settlement of the Diet Drug Claims of the Settling Claimants and in consideration for (i) the releases and dismissals provided by the Settling Claimants and (ii) the further obligations of the Settling Attorneys and Settling Claimants, all as provided herein, AHP shall pay you $\$ 200,000,000$ ('the Settlement Amount'), subject to the adjustments and terms set forth in paragraphs 7-14.").

27. Id. para. 13(B) ("The Settling Attorneys will move to decertify the class action claims against AHP in the Lawsuit. This settlement is contingent upon the entry of an order decertifying those class action claims ...."); id. para. 13(C) ("The Settling Attorneys will dismiss with prejudice the Lawsuit in its entirety, including all defendants and all claims. This settlement is contingent upon the entry of ... an order dismissing the Lawsuit in its entirety ...."); see also United States v. Gallion, 257 F.R.D. 141, 144 (E.D. Ky. 2009) (concluding as a matter of law that "the ... settlement was an aggregate settlement involving 440 claimants represented by the Defendants [Gallion and Cunningham] and Melbourne Mills"). 
The agreement between AHP and the plaintiffs' attorneys announced its goal of resolving all of the fen-phen claims of the clients represented by these attorneys: "This letter sets forth the final and complete terms on which American Home Products . . . will settle all Diet Drug Claims with the Settling Attorneys and the Settling Claimants." ${ }^{28}$ The lawyers affirmed that the "Settling Claimants" listed in the agreement included "all clients represented by the Settling Attorneys" who have diet drug claims and who opted out of the nationwide settlement class action or were not included in that class action. ${ }^{29}$

As often occurs in all-or-nothing settlements, the defendant disavowed any responsibility for allocation of the settlement amount:

The allocation of the Settlement Amount among the Settling Attorneys and Settling Claimants is the sole responsibility of the Settling Attorneys and the Settling Claimants. AHP has not stated or otherwise indicated any position or opinion on the allocation of the Settlement Amounts to any Settling Claimant and has not participated in any way in such allocation. ${ }^{30}$

The agreement instructed the plaintiffs' lawyers to allocate the money to the individual claimants. ${ }^{31}$

The agreement contained a walkaway clause that permitted AHP to terminate the agreement if fewer than $95 \%$ of the claimants provided releases. ${ }^{32}$ The phrasing of the provision, however, made it clear that the plaintiffs' lawyers were expected to provide releases from "each and every" fen-phen client:

Each and every Settling Claimant will sign a release in the form attached as Exhibit 1. The Settling Attorneys will be responsible for providing AHP with the signed releases for the Settling Claimants by September 1, 2001, unless AHP agrees to extend the deadline. If the Settling Attorneys do not provide signed releases for $95 \%$ of the Settling Claimants by the applicable deadline, and AHP does not extend the deadline, AHP shall have the right thereafter to declare this Letter Agreement terminated .... 33

\footnotetext{
28. Kentucky Fen-Phen Settlement Agreement, supra note 26, at intro. para.

29. Id. para. 3(A).

30. Id. para. 5(A).

31. Id. para. 6 .

32. Id. para. 10 .

33. Id.
} 
In addition to the duty to obtain releases from every client, the agreement imposed a duty on the plaintiffs' lawyers to obtain a dismissal with prejudice of each of their clients' lawsuits. ${ }^{34}$

The plaintiffs' lawyers prepared an allocation of the settlement funds, just as the agreement required. At that point, had they handled the settlement correctly, the lawyers could have gone forward with the settlement and avoided the criminal, civil, and disciplinary charges. First, they should have disclosed the full terms of the aggregate settlement to each of their clients and requested each client's informed consent as required by Kentucky's legal ethics rules. ${ }^{35}$ If the required releases and dismissals were obtained, and AHP funded the settlement, the lawyers should have given each client the full allocated amount minus costs and fees pursuant to their fee agreements. Had they done so, the lawyers would have earned over $\$ 60$ million in legitimate fees; ${ }^{36}$ their agreements with their clients entitled the lawyers to contingent fees of between 30 and $331 / 3 \%$.

Instead, the lawyers engaged in a course of conduct that landed them in prison. The lawyers did not inform each client of the full allocated amount. Rather, they offered their clients lower amounts, then used subsequent distributions as opportunities to seek additional fees beyond the amount specified in their fee agreements. ${ }^{37}$

The Kentucky Supreme Court's disbarment order describes the lawyers' handling of the settlement. It is worth quoting at length as it provides important details that connect the lawyers' misconduct to the all-or-nothing lump-sum nature of the settlement with AHP:

A settlement agreement was reached in May 2001 resulting in one lump sum payment to be divided among all plaintiffs. The agreement also provided that a portion of the settlement would be paid to [William Gallion] and two other attorneys, Melbourne Mills, Jr. and Shirley A. Cunningham, Jr., who were affiliated with the case. The agreement allowed [Gallion], Mills, and Cunningham to divide the settlement amount between plaintiffs at their discretion and also determine how much they personally were to be paid. The total amount of settlement funds to be distributed was $\$ 200,450,000$.

34. Id. para. 11 ("The Settling Attorneys will be responsible for providing AHP with an executed dismissal with prejudice for Settling Claimants (and, if applicable, the spouse and children) who have a pending civil action.").

35. See Ky. SCR 3.130(1.8)(g).

36. Andrew Wolfson, 2 sentenced in fen-phen fraud case, COURIER-JOURNAL (Louisville, Ky.), Aug. 18, 2009, at A1.

37. See Press Release, supra note 18. 
A staff member working with [Gallion], Mills, or Cunningham contacted each of the plaintiffs and informed them how much settlement money he would receive. The plaintiffs were never informed that their lawyers actually determined the amount of money they were to be given. If a plaintiff complained about the settlement amount, he was coerced by the attorneys or their staff to take the amount offered under the guise that it was what AHP had specifically offered them. Each plaintiff signed a confidentiality agreement and some plaintiffs were even told that they could go to jail if they discussed the terms of their individual settlement. At no point were the plaintiffs told about the total settlement arrangement from AHP. No plaintiff received a notice of the settlement process, the manner in which their settlement amounts were decided upon, or their right to opt out of the settlement and proceed to trial. ...

In June 2002, nearly $\$ 70$ million of the settlement funds had not been distributed. The money was improperly deposited in the personal accounts of the attorneys. An order was entered by [the judge] to give fifty percent of the remaining funds to the plaintiffs, and fifty percent to [Gallion], Mills, Cunningham and several other attorneys for "indemnification or contingent liabilities." The record shows that there were no "contingent liabilities."

In July 2002 another order was issued by the Boone Circuit Court. This divided any remaining funds between the attorneys for "outstanding litigation and administrative expenses" and a charitable organization which was to be created. No statement exists showing what outstanding litigation or administrative expenses existed at that time. The July 2002 order implied that all plaintiffs had consented to the creation of the charity. However, the record clearly shows that the plaintiffs did not knowingly consent to the creation of a non-profit charity like the one being proposed.

In January 2003, The Kentucky Fund for Healthy Living, Inc. was [established]. [Gallion], Mills, and Cunningham transferred \$20 million of the remaining settlement from their own personal accounts in order to fund the entity. [Gallion] was paid a salary for serving as one of the charity's board members.

In total, the attorneys received approximately $\$ 104,337,000$ from the total settlement.

38. Gallion v. Ky. Bar Ass'n, 266 S.W.3d 802, 803-04 (Ky. 2008); see also Cunningham v. Ky. Bar Ass'n, 266 S.W.3d 808 (Ky. 2008) (reciting identical facts with regard to Shirley Cunningham, Jr.); see also United States v. Gallion, 257 F.R.D. 141, 147 (E.D. Ky. 2009) (noting the federal court agreement with the Kentucky Supreme Court's "numerous legal conclusions regarding the Defendants' ethical violations"). 
The misconduct of the Kentucky fen-phen lawyers would not have occurred but for the all-or-nothing lump-sum nature of the deal offered by AHP. Obviously, this does not excuse the lawyers' conduct. The sentencing judge, imposing long prison terms on Gallion and Cunningham, emphasized the lawyers' "unbridled greed," noting that they would have earned millions of dollars in legitimate fees, but it "“appear[ed] to the court that they just wanted more." "39 The point of this study, however, is to look beyond the propensities of individual lawyers and to consider how the lump-sum aspect of the settlement created pressures and opportunities for wrongdoing.

First, it is worth asking whether the Kentucky fen-phen settlement was an all-or-nothing settlement. The $95 \%$ walkaway clause ${ }^{40}$ suggests that it was not all-or-nothing but rather a most-or-nothing settlement of the sort this paper suggests is less conducive to abuse. ${ }^{41}$ Other language in the agreement, however, makes it clear that the deal was to resolve all of the attorneys' clients' diet drug claims, and that in exchange for the lump sum of $\$ 200$ million, the lawyers were expected to deliver dismissals and releases for all 440 of their diet drug clients. ${ }^{42}$ The federal court, quoting the findings in the Kentucky Supreme Court disbarment orders, noted that the "settlement resulted in 'one lump sum payment to be divided among all plaintiffs." "43 During the first criminal trial, Gallion testified that he understood the deal to be a lump-sum payment in settlement of all remaining Kentucky diet drug claims. ${ }^{44}$

Treating the settlement as a lump sum gave the plaintiffs' lawyers control over the money, setting up the opportunity for misappropriation. AHP disavowed any role in allocating the money among the claimants. ${ }^{45}$ In the Kentucky settlement, like other settlements that contemplate participation by all of the claimants in the group, the defendant preferred to pay a lump sum and leave the allocation to plaintiffs' counsel.

With control over the money and pressure to get releases from all of their clients, the plaintiffs' lawyers reserved some of the money from the initial settlement amounts they relayed to clients. ${ }^{46}$ To the extent the

39. Wolfson, supra note 36.

40. Kentucky Fen-Phen Settlement Agreement, supra note 26, at para. 10.

41. See infra notes 234-35 and accompanying text.

42. See supra notes 28-29, 33-34 and accompanying text.

43. United States v. Gallion, 257 F.R.D. 141, 146 (E.D. Ky. 2009) (quoting Kentucky Supreme Court disbarment orders of William Gallion and Shirley Cunningham, Jr. (Oct. 23, 2008)).

44. See Andrew Wolfson, Diet-drug lawyer clashes with judge, COURIER-JOURNAL (Louisville, Ky.), June 14, 2008, at A1.

45. Kentucky Fen-Phen Settlement Agreement, supra note 26, at para. 3.

46. Gallion v. Ky. Bar Ass'n, 266 S.W.3d 802, 802-03 (Ky. 2008). 
lawyers did this in order to adjust offers as necessary to secure every client's assent, this is an example of what this Article labels the "slush fund problem.," Rather than seeking each client's informed consent based on full disclosure of the aggregate settlement terms, ${ }^{48}$ the lawyers pressured clients to accept the offers and failed to inform clients of the total deal or of the clients' right to decline the settlement. ${ }^{49}$

The lawyers' reservation of funds proved to be the starting point for multiple ethical breaches. In the face of the "allocation problem" common to lump-sum settlements, ${ }^{50}$ the lawyers took the wrong step of misleading their clients into believing that their individual offer amounts came directly from the defendant, rather than from their own lawyers. ${ }^{51}$ With funds remaining after the initial distribution, the lawyers took another wrong step by asking the court for additional fees out of a second distribution after the lawyers had already paid themselves the full amount to which their retainer agreements entitled them. ${ }^{52}$ They took a third wrong step by using remaining funds to create a not-for-profit entity, hiring themselves as paid managers. ${ }^{53}$ In the end, the plaintiffs' lawyers faced disciplinary sanctions, civil liability and criminal punishment for the misconduct that flowed from the pressures and opportunities created by an all-or-nothing lump-sum deal.

\section{B. The Napoli Fen-Phen Settlement}

In New York, another fen-phen aggregate settlement resulted in accusations that a law firm manipulated the settlement to its own advantage. Like the Kentucky settlement, the New York settlement involved a lump-sum payment by AHP to resolve a law firm's entire inventory of diet drug claims.

47. See infra Part III.D (discussing the slush fund problem)

48. See infra Part III.F (discussing the informed consent problem).

49. See Gallion, 266 S.W.3d at 803.

50. See infra Part III.B (discussing the allocation problem).

51. See Gallion, 266 S.W.3d at 803.

52. See id. at 804 .

53. Id.; Cunningham v. Ky. Bar Ass'n, 266 S.W.3d 808, 809 (Ky. 2008). See also United States v. Gallion, 257 F.R.D. 141, 150-51 (E.D. Ky. 2009) (barring defendants' proffered expert testimony concerning the cy pres trust on grounds that such trusts are unwarranted in non-class aggregate settlements). 
The law firm of Napoli, Kaiser \& Bern ("Napoli") represented approximately 5600 clients with fen-phen claims against AHP. ${ }^{54}$ Many of the clients had been referred by other law firms. When the fen-phen nationwide settlement class action was reached, Napoli advised its clients to opt out. ${ }^{55}$ AHP and Napoli then undertook negotiations to settle the firm's entire inventory of fen-phen claims. They reached a deal in which AHP "offered a large sum of money to settle virtually all claims.",56

After the settlement was consummated, some clients and other lawyers accused Napoli of misleading clients and manipulating the settlement to maximize the firm's legal fees. A class action was filed in federal court on behalf of the firm's clients. ${ }^{57}$ In New York state court, another law firm claimed that Napoli cheated other firms out of referral fees by allocating more settlement funds to its own clients than to clients who had been referred by other firms.

A New York judge described the plaintiffs' central accusations against Napoli:

The record on this motion... unfortunately raised serious questions regarding the settlement process herein, including claims that:

(1) claimants who were Napoli Firm clients were offered disproportionately larger settlements because the firm unfairly inflated settlement offers for its clients so that the attorneys' fees earned by the firm would be greater;

54. Buckwalter v. Napoli, Kaiser \& Bern, LLP, No. 01 Civ 10868LTSHBP, 2005 WL 736216, at $* 2$ (S.D.N.Y. Mar. 29, 2005).

55. Id.

56. Appel-Hole v. Wyeth-Ayerst Labs. (In re N.Y. Diet Drug Litig.), No. 700000/98, 2007 WL 969426, at*1 (N.Y. Sup. Ct. Mar. 27, 2007) (footnote omitted), aff'd, 850 N.Y.S.2d 408 (N.Y. App. 2008). The settlement amount was subject to a confidentiality agreement, see id. at $* 1 \mathrm{n} .3$, but news sources estimated the deal at \$1 billion; see Anthony DePalma, 9/11 Lawyer Made Name in Lawsuit on Diet Pills, N.Y. TIMES, Mar. 30, 2008, at 23 ("The details of the settlement were sealed by the courts, but The New York Law Journal and other publications estimated that it was worth $\$ 1$ billion and that it provided legal fees of roughly $\$ 350$ million.”).

57. Buckwalter, 2005 WL 736216, at*1. The court described the settlement as alleged in the Buckwalter complaint: "AHP offered to settle the claims of all of the individual Fen-Phen plaintiffs represented by NKB [Napoli] for a lump sum, provided that NKB would agree to stop its recruitment of additional clients and halt its prosecution of those cases it had already filed on behalf of existing clients. The lump sum settlement amount would be payable to NKB in installments, and determination of settlement amounts for individual claims, and the distribution of those amounts, would be left solely to the discretion of NKB." Id. at *2 (citations omitted). The complaint further alleged that Napoli settled "the claims of individuals who were referred by other lawyers for lower amounts than the claims of clients who had retained NKB directly in order to minimize the amounts NKB paid in referral fees," and that the firm "engaged in a scheme to convince the individual plaintiffs to accept the settlement amounts that they recommended through various pressure tactics, including misleading and inaccurate letters, coercive telephone conversations and hotel room meetings with clients ...." Id. at *3. 
(2) unknown to the claimants, their cases were not settled for an amount negotiated for each claimant with AHP, rather their claims were settled based upon the Napoli Firm's own evaluation of the value of each claim in light of a lump sum offer; [and]

(3) the Special Master appointed by the settling court did not make individual evaluations of the settlement offers in each case as was represented by the Napoli Firm to its clients and to the settling court ....

The court also provided information about the terms of Napoli's settlement agreement with AHP:

This Court has read the sealed settlement agreement. It is clearly a lump sum collective or aggregate settlement. The agreement itself is complex (as were the steps leading up to it) but in essence it provides that AHP agreed to pay a lump sum to the Napoli Firm, which sum was described as "the sum of the individual settlement amounts listed in Exhibit 3." One of the keys to understanding why this was an aggregate or collective settlement is that Exhibit 3 which contained the "individual settlement amounts" referred to in the settlement agreement, did not exist at the time the agreement was entered into. The amounts set forth in Exhibit 3 were not amounts negotiated for each client with AHP. The "individual settlement amounts" were not known at the time, they were to be subsequently determined in the process being challenged herein.

Like the Kentucky fen-phen settlement agreement, ${ }^{60}$ Napoli's agreement with AHP gave the plaintiffs' attorneys the responsibility of allocating the settlement funds among the claimants. ${ }^{61}$

The New York settlement as described by the court fits the description of an all-or-nothing deal. Although "a few clients out of the 5,000 did not agree to settle," ${ }^{\prime 62}$ the basic structure of the deal was that "AHP agreed to pay a lump sum to settle with a group of claimants." 63

Although the federal court dismissed the class action on the grounds that the claims were covered by an arbitration agreement, ${ }^{64}$ the claims

58. Appel-Hole, $2007 \mathrm{WL} 969426$, at $* 2$ (footnotes omitted).

59. Id. at $* 4$ (citations omitted)

60. Kentucky Fen-Phen Settlement Agreement, supra note 26, at para. 5(A)-(B).

61. Appel-Hole, $2007 \mathrm{WL} 969426$, at $* 4$.

62. $I d$. at $* 5$.

63. Id.; see also id. at *9 ("The Napoli Firm appears to have been offered one lump sum of money to settle all of its clients' cases who agreed to settle, provided a sufficient percentage agreed (it is also not denied by the Napoli Firm that the number of clients increased after the offer, further diluting the sum available for each claimant).”).

64. Buckwalter v. Napoli, Kaiser \& Bern, LLP, No. 01 Civ. 10868LTSHB, 2005 WL 736216, 
against Napoli eventually gained traction as objections to the settlement in the underlying diet drugs proceeding in New York state court. ${ }^{65}$ The New York judge ruled in 2007 "that a sufficient showing has been made that the Napoli Firm may have violated the Disciplinary Rules and may have made material misrepresentations in the Letter and the Form of Acceptance." ${ }^{\circ 6}$ The judge appeared particularly troubled by the allegations that Napoli deceived its clients about whether the individual settlement amounts had been negotiated with the defendant: "The representation to a client that a specific dollar amount was offered in a negotiation with the defendant to settle the client's case, when in fact the settlement offer was by the client's own attorney made upon the attorney's evaluation, if true, represents a serious breach of duty to the client." ${ }^{.67}$ The court permitted the referring law firm to intervene and ordered that the claims of misrepresentation and manipulation should be determined at trial; ${ }^{68}$ the order was affirmed on appeal. ${ }^{69}$ The intervenor complaint, filed in 2009, alleged that Napoli agreed to a lump-sum settlement with AHP; ${ }^{70}$ determined the allocations; ${ }^{71}$ and assigned values "fraudulently, unfairly, and unjustly" in order to maximize its net fees. ${ }^{72}$ The complaint further alleged, reminiscent of the Kentucky case, that the total assigned values of the settlements left a remainder, which Napoli failed to turn over to the settling clients. ${ }^{73}$ Adding insult to injury, in

at $* 9$ (S.D.N.Y. Mar. 29, 2005).

65. Appel-Hole, $2007 \mathrm{WL} 969426$, at *2. Earlier, in a separate lawsuit filed by the referring law firm against Napoli, the New York Appellate Division rejected the claims as an improper collateral attack on a previously approved settlement. Parker \& Waichman v. Napoli, 815 N.Y.S.2d 71, 74 (N.Y. App. Div. 2006).

66. Appel-Hole, 2007 WL 969426, at *11.

67. Id. at *9.

68. Id. at $* 11$

69. Appel-Hole v. Wyeth-Ayerst Labs., 850 N.Y.S.2d 408, 408 (N.Y. App. Div. 2008).

70. Intervenor Complaint of Parker Waichman, LLP at para. 41, Appel-Hole v. Wyeth-Ayerst Labs., No. 700000/98 (N.Y. Sup. Ct. Apr. 10, 2009) ("Upon information and belief, the resolution involved payment by AHP of lump sum amounts to Intervenor Defendants for discontinuing substantially all of their cases.").

71. Id. at para. 42 ("The amounts paid by AHP to settle the cases of diet drug plaintiffs were paid into several 'buckets' for settlement purposes rather than AHP allocating a specific amount for each Settled Client's case."); id. at para. 43 ("Upon information and belief, individual settlement amounts for each client were determined and then assigned by Intervenor Defendants.").

72. Id. at para. 44 ("Upon information and belief, Intervenor Defendants determined individual settlement amounts by fraudulently, unfairly, and unjustly assigning a settlement value to Direct Cases far above their actual worth and assigning a settlement value to cases referred from other attorneys, including the Referred Cases for amounts less than their actual worth."); id. at para. 45 ("Upon information and belief, Intervenor Defendants determined individual awards by fraudulently, unfairly, and unjustly assigning value to Direct Cases referred to them by certain attorneys far above the value assigned to cases referred from other attorneys, including the Referred Cases.").

73. Id. at para. 47 ("Upon information and belief, Intervenor Defendants assigned values to 
2009 Napoli's malpractice insurer filed a lawsuit to avoid defending and indemnifying the firm in the dispute over the fen-phen settlement. ${ }^{74}$

The brouhaha over Napoli's fen-phen settlement, like the trouble in Kentucky, depended on the lump-sum nature of the deal. By giving the plaintiffs' attorneys control over the allocation, the agreement set up the opportunity for abuse. One accusation - the primary basis of the referring law firm's claim against Napoli-grew out of lawyer-client and client-client conflicts of interest, in which lawyers have an interest in shifting settlement funds to directly retained clients rather than to referred clients in order to minimize referral fees to other law firms. ${ }^{75}$ Another accusation concerned reservation of money from the settlement amount. $^{76}$ These are problems that can arise only when plaintiffs' lawyers are given the responsibility of allocating settlement funds among their clients.

Other accusations concerned tactics to secure near-unanimous client participation in the settlement. Napoli was accused of using highpressure techniques to coerce clients to accept the settlement. ${ }^{77}$ It was accused, as well, of deceiving clients into believing that their settlement amounts were individually negotiated with the defendant and individually reviewed by the special master. ${ }^{78}$ These issues arise when settlements seek to bind nearly all members of the client group.

\section{The Locks Fen-Phen Settlement}

The diet drug litigation proved to be fertile ground for ethical disputes after AHP approached plaintiffs' law firms around the country

their existing inventory of Direct and Referred diet drug cases which left a balance of money remaining in possession of Intervenor Defendants from the gross settlement amounts paid by AHP."); id. at para. 49 ("Intervenor Defendants, instead of allocating the balance to existing clients, sought to attract new direct clients by, among other things, posting a message on the internet ... that it was the 'Last Chance for a Cash Award for Fen-Phen Cases' and that '[Napoli] can settle your case now, today."”); $i d$. at para. 50 ("Upon information and belief, none of the "Excess Settlement Funds' were paid to the then existing clients and their referring attorneys with respect to the Referred Cases...."); see also supra text accompanying notes 18-53 (discussing the Kentucky fen-phen settlement).

74. Complaint at 9-10, Westport Ins. Corp. v. Napoli, Kaiser \& Bern, LLP, 09-Civ-7433 (S.D.N.Y. Aug. 24, 2009).

75. See infra Part III.A (discussing conflict of interest problems).

76. See infra Part III.D (discussing slush fund problem).

77. Buckwalter v. Napoli, Kaiser \& Bern, LLP, No. 01Civ.10868LTSHBP, 2005 WL 736216, at *3 (S.D.N.Y. Mar. 29, 2005).

78. Appel-Hole v. Wyeth-Ayerst Labs. (In re N.Y. Diet Drug Litig.), No. 700000/98, 2007 WL 969426, at**2, 9-11 (N.Y. Sup. Ct. Mar. 27, 2007), aff'd, 850 N.Y.S.2d 408 (N.Y. App. Div. 2008); see also infra Part III.F (discussing informed consent problem). 
to negotiate settlements of each firm's inventory of cases. ${ }^{79}$ These settlements dealt with the claims of tens of thousands of diet drug plaintiffs who opted out of the national settlement class action.

In New Jersey, a dispute over a fen-phen settlement erupted as a battle between a fired lawyer and her former firm. ${ }^{80}$ The underlying allegations of misconduct against the firm strongly resembled certain allegations against the Kentucky lawyers and Napoli-that the firm withheld funds from the individual settlement amounts to adjust offers as necessary to secure clients' acceptance, and that the firm misallocated funds to maximize its own fees and avoid referral fees. ${ }^{81}$

Melissa Morris was a lawyer at Greitzer \& Locks (Locks). ${ }^{82}$ When she joined Locks, she brought one fen-phen client, Alan Weber. ${ }^{83}$ Morris became enmeshed in a dispute with her firm over the settlement of Weber's claim. ${ }^{84}$ Morris sued Locks under New Jersey's Conscientious Employee Protection Act, ${ }^{85}$ claiming that she was fired in retaliation for threatening to report the firm's unethical conduct in handling the settlement. ${ }^{86}$ A trial court granted summary judgment for Locks, but the appellate division reversed, finding that Morris had stated a valid claim and that the disputed facts must be determined by a jury. ${ }^{87}$

No definitive account of the facts is available, but Morris's version is spelled out in the appellate court's review of a summary judgment ruling. According to Morris, a Locks firm partner, James Pettit, told Morris that

79. See Mark Hamblett, Firm Accused of Intimidating Clients in Fen-Phen Litigation, N.Y. L.J., Dec. 12, 2001, at 1; Brenda Sapino Jeffreys, Stick to the Trial Plan: Breast Implant Litigation Taught Mike Gallagher How to Handle Fen-Phen Cases, TeX. LAw., Jan. 31, 2000, at 19; David J. Morrow, American Home to Settle Some 1,400 Fen-Phen Suits, N.Y. TIMES, Dec. 23, 1999, at C2; see also Stephanie Saul, Fen-Phen Case Lawyers Say They'll Reject Wyeth Offer, N.Y. TIMES, Feb. 17, 2005, at C5 (reporting that Wyeth offered a comprehensive settlement to resolve 63,000 claims with individual amounts ranging from $\$ 5000$ to $\$ 200,000$; according to the article, numerous plaintiffs' law firms agreed to the deal but several firms representing thousands of claimants refused to sign on).

80. Morris v. Greitzer \& Locks of N.J., L.L.C., No. A-4672-OGT3, 2009 WL 2525452, at **1, 4-5 (N.J. Super. Ct. App. Div. Aug. 20, 2009).

81. Id. at $* 6$

82. Locks was a major player in the fen-phen litigation; name partner Gene Locks was one of seven lawyers appointed as class counsel in the nationwide settlement class action. Brown v. Am. Home Prods. Corp. (In re Diet Drugs Prods. Liab. Litig.), No. 99-20593, 2000 WL 1222042, at*44 (E.D. Pa. Aug. 28, 2000), enforcement denied, No. 99-20593, 2003 WL 22594339 (E.D. Pa. Oct. 10, 2003). In addition, the Locks firm was one of the two lead plaintiffs' firms in the Amchem asbestos settlement class action. Carlough v. Amchem Prods., Inc., 5 F.3d 707, 709 (3d Cir. 1993).

83. Morris, 2009 WL 2525452, at*3.

84. Id. at **4-5.

85. N.J. STAT. ANN. § 34:19-1 to -8 (West 2000).

86. Morris, 2009 WL 2525452, at *5.

87. Id. at **18-19. 
he had settled the firm's diet drug cases, including Weber's, but he would not tell her the exact amount of the settlement. ${ }^{88}$ The next piece of Morris's account raises the slush fund concern:

Pettit told plaintiff that he was withholding ten percent of each dietdrug client's settlements in case any one or more of them objected to the amount of their settlement. [Morris] understood this to mean Pettit would use this money to remold objecting clients' settlement amounts. When [Morris] asked Pettit if this was ethical, he replied, "Melissa, I am doing the best I can.",

According to Morris, Pettit initially told her that Weber's settlement amount would be more than four times the amount Weber had authorized, but later Pettit reduced the amount to three times the authorized amount. ${ }^{90}$ Just as Napoli in New York was charged with misallocating settlement funds to minimize referral fees, ${ }^{91}$ Morris "alleged Pettit reduced the amount of Weber's settlement after he learned she was asserting a claim for a share of [Locks's] counsel fees."

Morris claimed that she "challenged the legal and ethical propriety of the manner in which the diet-drug cases were settled and the reduction to the amount of Weber's settlement. [Morris] stated she would report the improprieties." "93 Morris claimed that when it became clear that she was going to be fired, she removed her files and brought the Conscientious Employee Protection Act claim against Locks. ${ }^{94}$ The outcome remains to be seen.

\section{The Leeds Morelli Settlements}

Not all troublesome aggregate settlements involve product liability or mass torts. The law firm of Leeds, Morelli \& Brown ("Leeds Morelli") faced lawsuits from former clients alleging that the firm mishandled settlements of employment claims against Prudential Life Insurance Company, ${ }^{95}$ Nextel Communications, ${ }^{96}$ Prudential Securities, ${ }^{97}$

\footnotetext{
88. Id. at $* 3$.

89. Id.

90. Id. at *4

91. Buckwalter v. Napoli, Kaiser \& Bern, LLP, No. 01Civ.10868LTSHBP, 2005 WL 736216, at *3 (S.D.N.Y. Mar. 29, 2005)

92. Morris, 2009 WL 2525452, at*5.

93. Id. at *4.

94. Id.

95. See Lederman v. Prudential Life Ins. Co. of Am., 897 A.2d 362, 363 (N.J. Super. Ct. App. Div. 2006).
} 
Penguin Group, ${ }^{98}$ and Bear Stearns. ${ }^{99}$ Leeds Morelli represented numerous employees of these companies in potential claims including wrongful discharge and employment discrimination. The firm negotiated deals with the companies to resolve its clients' claims. The deals were structured to resolve all or nearly all of the Leeds Morelli clients' claims and to terminate Leeds Morelli's representation of plaintiffs against these defendants. The settlements became the subject of controversy when some clients, lawyers, and ethics experts argued that the deals created impermissible conflicts of interest and raised other ethical problems.

The settlement with Prudential Life Insurance Company gave rise to three lawsuits against Leeds Morelli. Leeds Morelli represented 359 Prudential employees who accused the company of wrongful conduct, including pressuring agents not to sell insurance to minorities. ${ }^{100}$ After Leeds Morelli negotiated a settlement with Prudential to resolve all of its clients' claims, some of those clients turned around and accused the law firm of selling them out. ${ }^{101}$ The essential allegations are described in this account of Lederman v. Prudential Life Insurance Co.:

According to the complaint, Prudential targeted 359 employees for dismissal in 1999 but had reason to believe they might file wrongful discharge suits. And the workers, particularly agents like Lederman, had reason to sue: They were facing dismissal for complaining about redlining and other abuses by Prudential, the complaint says.

So the company reached agreement with Leeds Morelli, which represented some of the employees, to call in the American Arbitration Association or equivalent neutrals to arbitrate claims by the 359 in secret. The employees went along, though whether they actually signed the pact remains a fact question.

On its face, the agreement seemed like a good deal for all. The employees, most of whom were at will, would have a forum to argue for severance pay and Prudential would pay their fees.

96. Johnson v. Nextel Commc'ns, Inc., No. 07 CV 8473(GBD), 2009 WL 928131 (S.D.N.Y. Mar. 31, 2009).

97. Vaughn v. Leeds, Morelli \& Brown, P.C., No. 04 Civ 8391(DLC), 2005 WL 1949468, at **1-2 (S.D.N.Y. Aug. 12, 2005), aff'd, 315 F. App'x 327 (2d Cir. 2009).

98. Ficklin v. Penguin Group (USA), Inc., No. L-3765-03, 2007 WL 560983, at*1 (N.J. Super. Ct. App. Div. Feb. 26, 2007).

99. See Lee v. Leeds, Morelli \& Brown, No. 8651/05 (N.Y. Supreme Ct. Mar. 22, 2005).

100. Lederman, 897 A.2d at 378 .

101. See id. at $378-79$. 
The company would avoid the potential embarrassment of court claims, including whistleblower suits alleging corporate wrongdoing. And it would avoid big payouts.

Lederman alleged in his suit, filed in November 2002, that Leeds Morelli and Prudential had reached a side agreement to cap the settlements at \$15 million, of which Leeds Morelli would receive onethird. That, the suit said, was fraud and commercial bribery that violated the rules of professional conduct and fooled the workers into thinking the ADR process would protect their rights. ${ }^{102}$

The allegations in Lederman were echoed in lawsuits filed by another former Prudential employee and Leeds Morelli client: Linda Guyden. In federal court, Guyden sought to vacate the award she received pursuant to the deal that Leeds Morelli had negotiated. ${ }^{103}$ In a state court case that was later consolidated with Lederman, Guyden sued Leeds Morelli for fraud, breach of fiduciary duty, and malpractice. ${ }^{104}$ The trial court ordered the plaintiffs to arbitration, but the appellate court reversed in 2006 and, as of 2009, the lawsuits against Leeds Morelli were going forward. ${ }^{105}$

Leeds Morelli's deal with Nextel Communications gave rise to even greater controversy. The law firm represented 587 claimants with employment-related claims against the company. ${ }^{106}$ Leeds Morelli and Nextel reached a Dispute Resolution and Settlement Agreement similar to the agreement the firm reached with Prudential. ${ }^{107}$ The Nextel settlement became the focus of heated debate when two leading legal ethics professors aired their disagreements about the role of ethics experts in the case. ${ }^{108}$

102. Henry Gottlieb, Whistleblower Alleges Conspiracy Between Plaintiffs Attorneys and Employer Voids Arbitration Agreement, N.J. L.J. (Apr. 13, 2006), available at http://www.law.com /jsp/PubArticle.jsp?id=90000545160; see also Lederman, 897 A.2d at 376-78.

103. Guyden v. Prudential Life Ins. Co., of Am., No. 08-3108, 2009 WL 1566792, at *1 (3d Cir. Jun. 5, 2009).

104. Mary Pat Gallagher, Bias Plaintiff Says Lawyer Sell-Out Warrants Vacating of Arbitration, N.J. L.J. (Apr. 8, 2008)

105. See Carmen Juri, Legal Fight Between Prudential, Ex-Employees Rolls on Dozens of Motions Prompt Another Continuance in Years-Long Lawsuit, STAR-LedGER (Newark, N.J.), Apr. 20, 2009; Martha Neil, Former Employees Say Insurer May Have Paid Their Lawyer \$5 Million, ABA JOURNAL ONLINE, Apr. 20, 2009.

106. Johnson v. Nextel Commc'ns, Inc., No. 07 CV 8473 (GBD), 2009 WL 928131, at *1 (S.D.N.Y. Mar. 31, 2009).

107. Id. at $* * 1-2$

108. See William H. Simon, The Market for Bad Legal Advice: Academic Professional Responsibility Consulting as an Example, 60 STAN. L. REV. 1555 (2008) [hereinafter Simon, The Market for Bad Legal Advice]; Bruce A. Green, The Market for Bad Legal Scholarship: William H. Simon's Experiment in Professional Regulation, 60 STAN. L. REV. 1605 (2008); William H. Simon, 
The settlement agreement set up a dispute resolution process for the entire group of Leeds Morelli clients with claims against Nextel. ${ }^{109}$ In exchange for resolution of the claims through the new process, Leeds Morelli agreed that the claimants' lawsuits and agency proceedings against Nextel would be dismissed. ${ }^{110}$ A few Leeds Morelli clients-9 out of 587-elected not to participate in the settlement. ${ }^{111}$ The language of the agreement, however, leaves no doubt that the parties' intent was to include every one of the clients in the deal. The agreement listed all of the clients who had retained Leeds Morelli to represent them in pursuing employment claims against Nextel. ${ }^{12}$ The law firm agreed that it did not represent any other clients with employment claims against Nextel nor did it intend to do so. ${ }^{113}$ The time frames were written with the expectation that all of the listed claimants would be included in the deal, and the agreement imposed penalties on Leeds Morelli for failure to meet those time frames:

LM\&B agrees that the claims of all Claimants will be processed and either resolved or fully submitted to arbitrators for decision [by the DRP Conclusion Date].... If all claims presented by all Claimants have not been processed and either resolved or fully submitted to arbitrators for decision in Binding Arbitration by the DRP Conclusion Date, Nextel may (i) withhold payment of any remaining installments to LM\&B until all claims presented by all Claimants have been processed and resolved and (ii) deduct from the final installment payment to LM\&B $\$ 50,000$ for each month after the DRP Conclusion Date that the processing and either resolution or full submission to arbitrators for decision in Binding Arbitration of all claims presented by all Claimants has not occurred .... ${ }^{114}$

Transparency is the Solution, Not the Problem: A Reply to Bruce Green, 60 STAN. L. REV. 1673 (2008).

109. Johnson, 2009 WL 928131, at *1.

110. Id. at $* * 1-2$

111. See Letter from Gregory I. Rasin to Jeffrey K. Brown 1 (Aug. 29, 2001) (listing nine claimants who "voluntarily opted out of the DRP pursuant to Amendment No. 2 to the Agreement").

112. Dispute Resolution and Settlement Agreement Between Nextel Communications and Leeds, Morelli \& Brown para. 1(a) (Sept. 28, 2000) [hereinafter Nextel Settlement Agreement], available at http://www2.law.columbia.edu/wsimon/pdf/LMB\%20Materials\%20referred\%20to\% 20in\%20the\%0Stanford\%20article.pdf.; see also id. Schedule 1 ("LM\&B represents that each current or former employee of the Companies or Job Seeker represented by LM\&B is listed below, and that each such listed person has retained LM\&B to represent him/her to pursue claims (other than worker's compensation claims) against the Companies arising from his/her current or former employment by the Companies or attempt to obtain employment with the Companies.").

113. Id. para. 1(c).

114. Id. para. 11(b) 
Moreover, the very structure of the deal, particularly the consultancy that Leeds Morelli would enter with Nextel, assumed that the firm would no longer represent plaintiffs with claims against Nextel after the settlement was concluded: "Immediately upon completion of the processing and resolution of all claims presented by all Claimants, time being of the essence, LM\&B shall be available to be retained and Nextel will retain $\mathrm{LM} \& \mathrm{~B}$, for a period of two years thereafter, as a legal consultant to the Companies...." "115 For this largely undefined assignment, Leeds Morelli would be paid \$2 million over two years. ${ }^{116}$

In addition to the $\$ 2$ million for the consultancy, Nextel agreed to pay Leeds Morelli a total of \$5.5 million to cover attorneys' fees for the settlement. ${ }^{117}$ The agreement stated that Nextel would pay Leeds Morelli \$2 million within three days after Leeds Morelli delivered signed agreements from all of the claimants, $\$ 1.5$ million when half of the claims had been resolved, "and the remaining \$2 million upon the processing and resolution of all remaining claims of all Claimants."118

A number of clients pursued lawsuits against Leeds Morelli claiming that by entering the deal with Nextel, the law firm breached its duties to its clients. A class action against Leeds Morelli in Colorado state court was settled, although the terms of the settlement are not public. ${ }^{119}$ Two clients who opted out of the first class action filed their own suit against the law firm; they lost in a jury trial. ${ }^{120}$ The third case, Johnson v. Nextel Communications, a class action against both Leeds Morelli and Nextel, was filed in New Jersey state court but was removed and transferred to the Southern District of New York. ${ }^{121}$ The lawyer for the Johnson class also represented the Lederman plaintiffs in their claims against Leeds Morelli concerning the Prudential settlement. ${ }^{122}$

At their core, the former clients' claims against Leeds Morelli were about collusion. In both the Prudential cases and the Nextel cases, the employees who had been represented by Leeds Morelli complained that

\footnotetext{
115. Id. para. 12 .

116. Id. para. 12 ("Nextel will pay LM\&B a consultancy fee of $\$ 83,333.34$ per month for 24 months for such services.”).

117. Id. at para. 11(a).

118. Id. para. 11(a)

119. See Simon, The Market for Bad Legal Advice, supra note 108, at 1578 n.75 (noting that the record in Foster v. Leeds, Morelli \& Brown, No. 02-CV-1484 (Colo. Dist. Ct. 2002), has been sealed and no one is permitted to discuss the terms of the settlement).

120. Id.

121. Johnson v. Nextel Commc'ns, Inc., No. 06-CV-5547 (DMC), 2007 WL 2814649, at *1 (D.N.J. Sept. 21, 2007).

122. Gallagher, supra note 104.
} 
their law firm's loyalty was compromised by a deal the firm struck with the opposition. ${ }^{123}$ Instead of representing the employees with undivided loyalty, the former clients claimed, the firm forged a mutually advantageous relationship with its clients' adversaries.

The essence of Plaintiffs' claims against their former lawyers is that, pursuant to an agreement... Nextel bribed the attorneys to compromise Plaintiffs' claims against Nextel on terms favorable to Nextel. ... The foundation of many of the claims asserted against the Attorney Defendants is that there were secret payments made by Nextel to $\mathrm{LM} \& \mathrm{~B}$ and that the entire structure of the ADR process ... was unethical. ${ }^{124}$

Leeds Morelli contended that the arrangement was advantageous for its clients. The concern that gave rise to so many lawsuits, however, was that Leeds Morelli's interests in the deal aligned with those of the defendants and diverged from the interests of its own clients. Leeds Morelli, the lawsuits claimed, struck deals in which the firm stood to gain millions of dollars on the condition that it could persuade its clients to participate in the settlement. As one of the former Prudential employees put it, "If your attorney is colluding with the person you are suing, that's a problem.".125

\section{E. The Vioxx Settlement ${ }^{126}$}

The Merck pharmaceutical company, facing mass litigation over its painkiller Vioxx, negotiated an agreement in 2007 with a group of plaintiffs' lawyers to resolve the claims of about 50,000 plaintiffs for $\$ 4.85$ billion. $^{127}$ The deal came after several years of hard-fought litigation over claims that the drug caused heart attacks and strokes.

On the surface, the Vioxx deal was not all-or-nothing. It was structured as an $85 \%$ walkaway deal. ${ }^{128}$ In other words, the agreement provided that Merck could terminate the deal unless it received releases

\footnotetext{
123. Id.; Lederman v. Prudential Life Ins. Co., 897 A.2d 362, 366 (N.J. Super. Ct. App. Div. 2006)

124. Johnson, 2007 WL 2814649 , at *1.

125. Juri, supra note 105

126. For a discussion of the Vioxx settlement as an attempt to obtain closure in a mass tort settlement, see Erichson \& Zipursky, supra note 2.

127. See Settlement Agreement Between Merck \& Co., Inc. and the Counsel Listed on the Signature Pages Hereto (Nov. 9, 2007) [hereinafter Vioxx Settlement Agreement], available at http://www.merck.com/newsroom/vioxx/pdf/Settlement_Agreement.pdf.

128. Id. $\S 11.1$.
} 
from at least $85 \%$ of the claimants in certain categories as well as $85 \%$ of the claimants overall. ${ }^{129}$ Other terms of the agreement, however, rendered this walkaway clause almost entirely superfluous and made the deal an all-or-nothing proposition for each law firm that represented Vioxx plaintiffs. ${ }^{130}$ For a law firm to participate - that is, for any of its clients to get compensation through the settlement- the law firm was obligated to recommend the settlement to all of its eligible clients. ${ }^{131}$ Moreover, if any clients chose not to participate in the settlement, the lawyer was required to withdraw from representing the non-settling clients. ${ }^{132}$ Any client who declined the settlement faced the prospect of losing a lawyer and finding that every other lawyer handling Vioxx claims was unavailable. Unsurprisingly, the overwhelming majority of eligible claimants decided to participate in the settlement. ${ }^{133}$

The mandatory recommendation provision took the form of an affirmation by plaintiffs' counsel: "By submitting an Enrollment Form, the Enrolling Counsel affirms that he has recommended, or... will recommend by no later than [the deadline], to $100 \%$ of the Eligible Claimants represented by such Enrolling Counsel that such Eligible Claimants enroll in the Program."

This mandatory recommendation provision was immediately followed by the real kicker, the mandatory withdrawal provision:

If any such Eligible Claimant disregards such recommendation, or for any other reason fails (or has failed) to submit a non-deficient and nondefective Enrollment Form on or before [the deadline]... such enrolling counsel shall ... to the extent permitted by the equivalents to Rules 1.16 and 5.6 of the ABA Model Rules of Professional Conduct in the relevant jurisdiction(s), (i) take . . . all necessary steps to disengage and withdraw from the representation of such Eligible Claimant and to forego any Interest in such Eligible Claimant and (ii) cause ... each other Enrolling Counsel, and each other counsel with an Interest in any Enrolled Program Claimant, which has an Interest in such Eligible Claimant to do the same. ${ }^{135}$

\footnotetext{
129. Id.

130. See id. $\S \S 1.2 .8 \cdot 1-1.2 .8 .2$

131. Id. $\$ 1.2 .8 .1$.

132. Id. § 1.2.8.2. eligible claimants had enrolled).

134. Vioxx Settlement Agreement, supra note 127, § 1.2.8.1.

135. Id. $\S 1.2 .8 .2$.
}

133. See Claims Administrator Court Report No. 13 (Dec. 19, 2008) at 2, available at www.browngreer.com/vioxxsettlement/images/pdfs/mdlreport_121908.pdf (reporting that $99.79 \%$ of 
These two provisions made the Vioxx settlement a bundle of firmby-firm all-or-nothing deals, notwithstanding the overall requirement of $85 \%$ participation. Lest there be any doubt that the signatories intended the deal to function as a set of firm-by-firm all-or-nothing settlements, the agreement made the goal explicit: "The parties agree that a key objective of the Program is that, with respect to any counsel with an Interest in the claims of any Enrolled Program Claimant, all other Eligible Claimants in which such counsel has an Interest shall be enrolled in the Program."136

Samuel Issacharoff framed the challenge of the Vioxx settlement in part as a response to Amchem and Ortiz:

The difficult issue was how to create an effective bill of peace that would bring a reasonable (and reasonably certain) end to the litigation, enabling the plaintiffs to be compensated and Merck to obtain closure. A publicly ordered settlement through the use of a class action was too unwieldy because of the elevated burdens on organizing a class after Amchem and Ortiz .....

The unusual provisions in the Vioxx settlement, in Issacharoff's view, offered a firm-by-firm guarantee of comprehensiveness:

The novel feature of the settlement was that while the offer was made to each Vioxx plaintiff individually, the offer was only valid if accepted by all the clients represented by any particular attorney or law firm. In order to provide closure, however - and to substitute for the inability to use effectively the class action device...-the offer required any participating lawyer to certify that all his or her clients had agreed to the terms. In broad outlines, the offer provided closure with each firm independently (subject to an overall 85 percent acceptance rate to be effective) or it would not become effective. ${ }^{13}$

As soon as the deal was announced, legal ethicists voiced concerns that the deal violated the plaintiffs' lawyers' duties to their clients. ${ }^{139}$

136. Id. § 1.2.7. See also id. Recital G ("A key objective of the Program is that, with respect to any counsel with an Interest in the claims of any Enrolled Program Claimant, all other Eligible Claimants in which such counsel has an Interest shall be enrolled in the Program.").

137. Issacharoff, supra note 6 , at 217.

138. Id. at 218 .

139. See, e.g., Daniel Costello, Vioxx Deal May Cause Pain, L.A. Times, Nov. 15, 2007, at C1; Nathan Koppel, Vioxx Plaintiffs' Choice: Settle or Lose Their Lawyer, WAll ST. J., Nov. 16, 2007, at B1; Adam Liptak, In Vioxx Settlement, Testing a Legal Ideal: A Lawyer's Loyalty, N.Y. TimeS, Jan. 22, 2008, at A12; Anthony Sebok \& Benjamin Zipursky, Getting with the Program: The Vioxx Settlement, FindLAw, Nov. 20, 2007, http://writ.lp.findlaw.com/sebok/20071120.html. These early critics included myself. See Posting of Howard M. Erichson to the Mass Tort Litigation Blog, 
The mandatory recommendation provision, critics contended, violated the duty to give independent and loyal advice. ${ }^{140}$ The mandatory withdrawal provision, they said, violated the duty not to restrict one's law practice as part of a settlement, ${ }^{141}$ disregarded the constraints on termination of the lawyer-client relationship, ${ }^{142}$ and contravened the principle that the decision of whether to accept a settlement belongs to the client. ${ }^{143}$

When some of the plaintiffs' lawyers challenged the deal in court and asked for a declaratory judgment that the mandatory recommendation and mandatory withdrawal provisions were unenforceable ${ }^{144}$ Merck and the negotiating plaintiffs' lawyers agreed to amend the agreement by adding the following language: "Each Enrolling Counsel is expected to exercise his or her independent judgment in the best interest of each client individually before determining whether to recommend enrollment in the Program." 145 The amendment removed neither the mandatory recommendation provision nor the mandatory withdrawal provision, ${ }^{146}$ but apparently it satisfied the objecting lawyers sufficiently to end the matter.

The Connecticut Bar Association Committee on Professional Ethics issued an ethics opinion about the Vioxx settlement's mandatory recommendation and mandatory withdrawal clauses, concluding that both provisions were unethical:

http://lawprofessors.typepad.com/mass_tort_litigation/2007/11/the-vioxx-settl.html (Nov. 10, 2007).

140. Model RULES OF PROF'L CONDUCT R. 1.7(a)(2), 2.1 (2009).

141. Model Rules of Prof'L CONDUCT R. 5.6(b) (2009). The agreement anticipates this objection, stating that "nothing in this Agreement is intended to operate as a 'restriction' on the right of any Claimant's counsel to practice law within the meaning of the equivalent to Rule 5.6(b) of the ABA Model Rules of Professional Conduct in any jurisdiction in which Claimant's Counsel practices or whose rules may otherwise apply." Vioxx Settlement Agreement, supra note 127, § 1.2.8.

142. Model RULES OF PROF'L CONDUCT R. 1.16 (2009). One report quoted legal ethics expert Stephen Gillers on the illegality of the Vioxx agreement's mandatory withdrawal provision: "This is a black-and-white issue. ... Clients are not inventory that lawyers can just shed when they become inconvenient. It's forbidden." Costello, supra note 139.

143. Model Rules of Prof'L Conduct R. 1.2(a) (2009); see also Model Rules of Prof'L CONDUCT R. 1.8(g) (2009) (requiring informed consent for aggregate settlements).

144. See, e.g., Memorandum in Support of Certain Plaintiffs' and Their Counsels' Motion for Declaratory Judgment that Certain Provisions of the Settlement Agreement are Unenforceable, In re Vioxx Prods. Liab. Litig., 650 F. Supp. 2d 549 (E.D. La. Jan. 3, 2008) (No. 1657), 2008 WL 83836.

145. See Heather Won Tesoriero, Merck's Prospects Brighten for Vioxx Settlement, Wall St. J., Jan. 19, 2008, at A3.

146. Id. ("Lawyers for both sides said this is a point of clarification but not a substantive change.").

147. Id. (reporting that the attorneys "appear to have been mollified" by the amendment and had withdrawn their motions or indicated their intention to do so). 
One provision compels plaintiffs' counsel to give the same advice to all of her clients. The other, to the extent permitted by Rule 1.16 and Rule 5.6, compels her to withdraw from representing clients who reject her advice to settle. In our opinion, for the reasons set forth below, both provisions compel lawyers to violate the Rules of Professional Conduct. $^{148}$

First, the opinion explained that the mandatory recommendation provision asked plaintiffs" lawyers to "do the impossible," because a lawyer cannot provide independent professional judgment to each client if the agreement restricts the advice that the lawyer may give. ${ }^{149}$ "Applying [i]ndependent professional judgment," the opinion says, "she may believe that some clients should accept the settlement while others should reject it." 150 Turning to the mandatory withdrawal provision, the Connecticut opinion emphasized that "a lawyer may not threaten to withdraw or withdraw from a case because the client rejects a settlement offer." 151

\section{F. The Phillips Chemical Plant Settlement}

After a series of explosions at a Phillips 66 chemical plant in Texas killed twenty-three workers and injured hundreds of others, 126 of the victims retained a group of leading mass tort lawyers-Umphrey, Burrow, Reaud, Williams \& Bailey ("Umphrey Burrow")- to pursue wrongful death and personal injury claims. ${ }^{152}$ Umphrey Burrow negotiated a settlement of these claims for approximately $\$ 190$ million and received a contingent fee of more than $\$ 60$ million. ${ }^{153}$ A number of the plaintiffs then filed ethics grievances and a civil lawsuit against the Umphrey Burrow lawyers, claiming that the lawyers engaged in professional misconduct in connection with the settlement. ${ }^{154}$

Burrow v. Arce became a hot button among mass litigators and legal ethicists because of the Texas Supreme Court's holding that a lawyer's breach of fiduciary duty may result in fee forfeiture even without proof of actual damages. ${ }^{155}$ For purposes of this Article, however, the case is

\footnotetext{
148. Conn. Bar Ass'n, Informal Op. 08-01 (Feb. 20, 2008) (Obligations of Plaintiffs' Counsel under a Particular Aggregate Settlement Agreement).

149. $I d$.

150. Id.

151. Id.

152. Burrow v. Arce, 997 S.W.2d 229, 232 (Tex. 1999).

153. Id.

154. Id.

155. Id. at 239-40.
} 
significant not as a ruling about remedies, but rather as an example of an all-or-nothing settlement gone awry.

In the lawsuit, forty-nine of the former Umphrey Burrow clients sued the lawyers for breach of fiduciary duty, fraud, deceptive trade practices, negligence, and breach of contract. ${ }^{156}$ The court of appeals described the plaintiffs' contentions:

According to [the plaintiffs], [the Umphrey Burrow lawyers] did not develop or evaluate their claims individually, and instead, without discussion or authority, reached an "aggregate settlement" with Phillips for the entire suit. Only then were [the plaintiffs] "summoned" for a brief, twenty-minute meeting to discuss the settlement arrangements. [The plaintiffs] allege [that the Umphrey Burrow lawyers] lied, and/or intimidated them into accepting the settlement and, in the process, "skimmed-off" sixty million dollars in attorneys' fees.

A news report based on interviews with plaintiffs fleshes out the accusations, including the charge that some clients were offered additional money when they objected to the initial amounts offered:

Umphrey Burrow lawyers had relatively little contact with their 126 clients - none, in some cases - until all were summoned to the firm's offices in late February 1991 to hear that Phillips had offered to settle for sums from $\$ 25,000$ to $\$ 9.5$ million.

Court documents and interviews with plaintiffs show that in meetings scheduled to last just 20 minutes, each was urged to take the money. Twenty-six plaintiffs who objected were offered larger sums. Some plaintiffs said they were warned that Umphrey Burrow would not pursue their cases in court. Others said they were also told that if they sought other counsel, Umphrey Burrow would still be entitled to a third of their compensation under the contingency contract.

In the end, all but a handful agreed to settle for a sum totaling $\$ 190$ million, of which Umphrey Burrow received $\$ 65$ million.

156. Id. at 232

157. Arce v. Burrow, 958 S.W.2d 239, 243 (Tex. App. 1997), aff'd in relevant part, 997 S.W.2d 229 (Tex. 1999); see also Burrow, 997 S.W.2d at 232 ("The plaintiffs contend: ... . The attorneys settled all the claims in the aggregate and allocated dollar figures to the plaintiffs without regard to individual conditions and damages. No plaintiff was allowed to meet with an attorney for more than about twenty minutes, and any plaintiff who expressed reservations about the settlement was threatened by the attorney with being afforded no recovery at all.”).

158. Peter Passell, Challenge to Multimillion-Dollar Settlement Threatens Top Texas Lawyers, N.Y. TIMES, Mar. 24, 1995, at B6. 
The allegations in Burrow raised many of the issues that have come up in connection with other all-or-nothing settlements. The Burrow plaintiffs accused their lawyers of carelessness in allocating settlement funds. ${ }^{159}$ While disenchanted clients may accuse lawyers of carelessness even in individual settlement negotiations, the charge rings truer in mass aggregate settlements where a lawyer's fee is based on the total amount and thus the financial incentive does not encourage expending significant resources on determining a fair allocation. Beyond careless allocation, the Burrow plaintiffs accused their lawyers of a particular form of misallocation: raising offers to clients who objected to initial settlement amounts. ${ }^{160}$ Reminiscent of charges concerning fen-phen settlements, this type of misallocation is problematic both because it involves a client-client conflict of interest and because it involves deceptive conduct if the lawyers conveyed "offers" to their clients as if those offers came from the defendant. ${ }^{161}$ Finally, the Burrow plaintiffs accused their lawyers of pressuring them to accept the settlement while failing to disclose the full scope of the deal. In other words, like the clients in a number of other all-or-nothing settlements, these plaintiffs accused their lawyers of failing to obtain the clients' genuine informed consent to the aggregate settlement. ${ }^{162}$

The Umphrey Burrow lawyers initially won summary judgment on the grounds that the plaintiffs could not show actual damages, but the Texas Supreme Court reversed, holding that fee forfeiture could be a remedy for a lawyer's breach of fiduciary duty even without actual damages. ${ }^{163}$ Three of the Umphrey Burrow lawyers settled with the plaintiffs while the appeal was pending, ${ }^{164}$ and the remaining claims were settled after the Texas Supreme Court decision was handed down. ${ }^{165}$

\section{The Problems OF ALL-OR-NothING SeTtLEMENTS}

At least seven types of problems arise from all-or-nothing settlements: (1) conflict of interest problems, (2) allocation problems, (3)

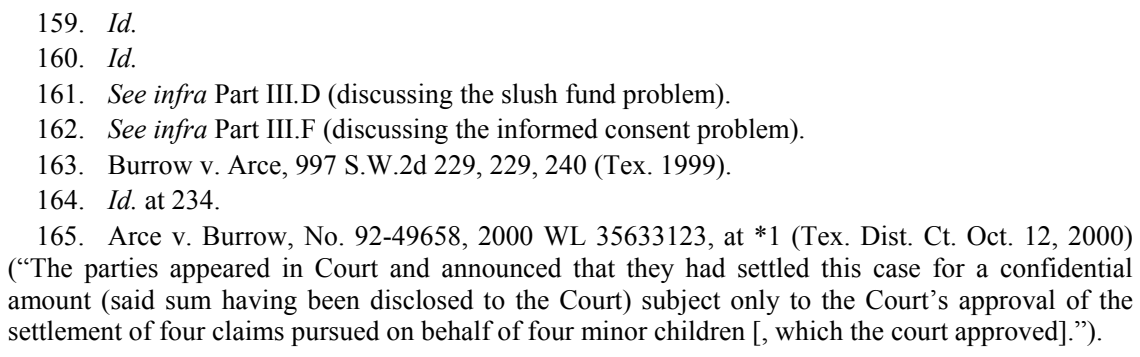


the holdout problem, (4) the slush fund problem, (5) the loyalty problem, (6) the informed consent problem, and (7) the collusion problem. These problems overlap substantially, ${ }^{166}$ and arguably the first categoryconflicts of interest-subsumes the rest. Some of these problems (conflict of interest, allocation, informed consent) are fundamental aspects of all-or-nothing settlements, while others (holdout, slush fund, loyalty) suggest problems that may arise in some cases. The list is not meant to be exhaustive. Nonetheless, breaking down the issues into discrete types of problems is useful for understanding the pressures and opportunities for abuse that arise when defendants insist that a settlement include all or nearly all claimants.

\section{A. Conflict of Interest Problems}

At bottom, all of the problems with all-or-nothing settlements may be understood as conflict of interest problems. All-or-nothing settlements create both client-client and lawyer-client conflicts of interest. ${ }^{167}$ In the language of the Rules of Professional Conduct, such conflicts of interest present "a significant risk that the representation of one or more clients will be materially limited by the lawyer's responsibilities to another client... or by a personal interest of the lawyer." $" 168$

Allocation of settlement funds among a lawyer's clients presents a client-client conflict. Any decision to give clients different settlement amounts - or to give differently situated clients the same settlement amount-necessarily involves choices that benefit some clients while harming others. Similarly, if the settlement involves a matrix, points, or categories, any decision about how to value a claim based on particular injuries and other factors involves choices that benefit some clients while harming others. ${ }^{169}$ This sort of conflict exists even if a lawyer negotiates

166. Elizabeth Chamblee Burch treats the holdout problem, client-client conflicts of interest, lawyer-client conflicts of interest, and allocation issues as aspects of the broader problem of “disunity." Elizabeth Chamblee Burch, Litigating Groups, 61 ALA. L. REV. 1, 16 (2009).

167. See Howard M. Erichson, A Typology of Aggregate Settlements, 80 NOTRE DAME L. REV. 1769,1798 (2005) ("All-or-nothing deals present the most extreme form of conflict because they give the lawyer a powerful incentive to pressure every client . . to accept the agreement.").

168. Model Rules of PROF’L CONDUCT R. 1.7(a)(2) (2009).

169. See Erichson, supra note 167, at 1799-1806 (identifying collective allocation as a source of conflicts of interest justifying the informed consent requirement of the aggregate settlement rule). The comments to the American Law Institute's Principles of the Law of Aggregate Litigation explain the importance of collective allocation:

[A]llocation is collective if the value of any claimant's claim is determined by a method other than individual, claimant-by-claimant analysis. For example, an allocation is 
with the defendant to determine a detailed matrix of settlement values, but the conflict appears in its rawest form when a defendant offers a lump sum and leaves it to the plaintiffs' counsel to allocate the money. ${ }^{170}$

Not only do client-client conflicts arise from the allocation process in aggregate settlements, they also arise from the requirement of including all claimants in the deal. ${ }^{171}$ When a settlement requires that all of a lawyer's clients participate in the deal, it creates a conflict between those clients who wish to accept the settlement and those who might otherwise choose, or be advised, to decline the settlement. The decision of some clients to decline the settlement impairs the ability of other clients to get the deal done. Client-client conflicts occur whenever a deal is conditioned on terms that make clients' settlements interdependent. ${ }^{172}$ When a settlement contains a walkaway clause that conditions the deal upon $85 \%$ or $90 \%$ participation, the conflict is relatively mild because of the safety valve that permits a number of clients to decline the settlement without blowing the deal for everyone else. When a settlement requires $100 \%$ participation, however, the client-client conflict makes it extremely difficult for a lawyer to give unbiased counsel to a client who wishes to decline the offer.

Even more worrisome than these client-client conflicts of interest, all-or-nothing settlements create lawyer-client conflicts that present

collective whenever a defendant conditions the settlement of the claims of multiple claimants and leaves to claimants' counsel the responsibility of proposing the allocation of that money among the members of the group. When a defendant conditions its offer to claimants' counsel to settle all existing claims on a lump-sum basis, the claims are interdependent because the parties have not assessed the precise value of each claimant's claim in arriving at the settlement figure. More realistically, the defendant's and claimants' attorneys simply looked at the claims as a whole and negotiated a figure that would compensate claimants with either an average award or an award based on a matrix of categories (e.g., depending on the nature of the injuries). Because the settlement does not reflect the value of each individual's claim, there is a possibility that the settlement undervalues some claims relative to others, or in any other way fails to provide equity in treatment among the affected claimants.

AGGREGATE LitigAtion, supra note $5, \S 3.16 \mathrm{cmt}$. c.

170. Erichson, supra note 167, at 1787-88, 1801.

171. Similarly, a provision that a lawyer must recommend a settlement to all or none of the lawyer's clients creates a client-client conflict. See Conn. Bar Ass'n Informal Op. 08-01 (Feb. 20, 2008) ("The agreement requires the lawyer to treat her clients as if they had agreed to be part of a group and to put the interests of the group above those of individual clients, a requirement that creates a conflict of interest.").

172. See Erichson, supra note 167, at 1796-99 (identifying collective conditionality as a source of conflicts of interest justifying the informed consent requirement of the aggregate settlement rule); see also AGGREGATE LitigAtion, supra note 5, $\S 3.16(\mathrm{~b})(1)$, cmt. b (describing collective conditionality as a form of interdependence in aggregate settlements); Tilzer v. Davis, Bethune \& Jones L.L.C., 204 P.3d 617, 629 (Kan. 2009) ("There was collective conditionality because the pharmaceutical companies were granted the right to opt out of the settlement if fewer than all of the covered plaintiffs accepted the proposed settlement."). 
significant opportunities and incentives for abuse. Some of these lawyerclient conflicts involve allocation. If a law firm agrees to pay referral fees for certain clients but other clients retained the firm directly, the firm has an interest in maximizing settlement amounts for the direct clients. ${ }^{173}$ In litigation over both the Napoli firm's fen-phen settlement in New York and the Locks firm's fen-phen settlement in New Jersey, the lawyers were accused of allocating less settlement money to certain clients to minimize referral fees. ${ }^{174}$

Another lawyer-client conflict arises whenever a deal is conditioned upon unanimity. All-or-nothing settlements pit the lawyer's interest in closing the deal against the interests of any clients who might wish to decline the settlement. If a lawyer has a one-third contingent fee arrangement and negotiates a $\$ 100$ million aggregate settlement on behalf of a large group of clients, the lawyer stands to earn over \$33 million if the deal goes through. If the deal is conditioned on full participation, the lawyer's fee depends on each client's willingness to settle. On the one hand, the lawyer has a duty to counsel each client about the right to decline the settlement and about the possible downsides of the deal, but on the other hand, the lawyer stands to lose millions of dollars if any client says no. As with the client-client conflict, this lawyer-client conflict may occur in any settlement conditioned upon a given level of participation, but settlements with $90 \%$ walkaway clauses or similar terms leave enough of a safety valve to alleviate much of the problem. All-or-nothing provisions, or other terms that push for near unanimity, exacerbate the conflict by putting the lawyer's fee at risk if the lawyer fails to obtain every client's assent to the deal. Arguably, a lawyer-client conflict exists whenever a contingent fee lawyer advises a single client about a settlement because the lawyer's fee may depend on the client's decision, but that level of conflict is inherent in virtually every lawyer-client relationship. What makes the all-or-nothing settlement troubling is the extent to which it ups the ante

173. See Erichson, supra note 167, at 1801-02 (describing how this situation can lead to lawyers favoring some clients over others); Burch, supra note 166. Paul Rheingold explains the interests that might lead to favoritism if settlement allocation is left to the plaintiffs' lawyer:

A law firm with a large inventory has some cases referred to it, whereby it has to give up a forwarding fee. Other cases came directly from the client. The more the settlements are paid to those who have no forwarder, the more the law firm makes. The law firm will, therefore, be more inclined to favor those clients who came directly to the law firm. Other examples of favoring one client over another include favoring a "squeaky wheel" client, favoring a relative, or favoring a friend of the family.

Paul D. Rheingold, Ethical Constraints on Aggregated Settlements of Mass Tort Cases, 31 LoY. L.A. L. REv. 395, 396-97 (1998).

174. See supra parts II.B and II.C. 
on the lawyer-client conflict by making the entire deal, and potentially the lawyer's entire fee, subject to the decision of each individual client.

\section{B. Allocation Problems}

All-or-nothing settlements tend to saddle plaintiffs' lawyers with the problem of allocating settlement funds. When the terms leave no significant possibility that some plaintiffs will decline a settlement while others accept it, the defendant has little reason to care about the allocation among plaintiffs. From the defendant's perspective, it is a lump-sum deal. Defendants in such settlements often explicitly disavow any involvement in allocating settlement funds among the claimants.

The Kentucky fen-phen settlement agreement specified that allocating the \$200 million among the 441 claimants was "the sole responsibility of the Settling Attorneys and the Settling Claimants."175 Similarly, Napoli agreed that the "determination of the individual settlement amounts for each of the Settling Claimants will be set forth in [a document prepared] by the Settling Attorneys ...."176

Defendants have at least two reasons to stay out of the allocation business. First, allocation of settlement amounts can be a timeconsuming and expensive process; parties avoid that burden unless they have a reason to undertake it. Second, a defendant in mass litigation prefers not to be pinned to any individual settlement because the amount, if known, might create expectations among other claimants who would treat it as a floor in subsequent negotiations. For a defendant, allocation ignorance is one of the luxuries of a lump-sum settlement. In a settlement that contemplates incomplete participation, defendants cannot entirely ignore allocation because savvy plaintiffs' attorneys could steer funds to plaintiffs with weaker claims, while encouraging stronger claimants to decline the settlement.

For the plaintiffs' lawyer, the job of allocating settlement funds is problematic. The client-client conflict of interest is palpable; it is a zerosum game. Moreover, the typical contingent fee gives plaintiffs' lawyers a strong incentive to maximize the total size of a settlement, but little incentive to devote resources to ensuring a fair allocation of the funds once the total size has been determined. Thus, when clients accused the

175. Kentucky Fen-Phen Settlement Agreement, supra note 26, para. 5(a); see also supra notes 30-31 and accompanying text.

176. Appel-Hole v. Wyeth-Ayerst Labs. (In re N.Y. Diet Drug Litig.), No. 700000/98, 2007 WL 969426 , at $* 4$ (N.Y. Sup. Ct. Mar. 27, 2007) (quoting section 5(a) of the settlement agreement), aff'd, 850 N.Y.S.2d 408 (N.Y. App. 2008); see also supra text accompanying note 61. 
Umphrey Burrow lawyers of carelessness in determining individual amounts in the Phillips chemical plant settlement, ${ }^{177}$ the charge may have resonated because the fee incentives in all-or-nothing settlements encourage a certain amount of lawyer apathy concerning individual allocations. Worse, the lawyer may have affirmative incentives to misallocate, for example to minimize referral fees. Mediators and other third parties are available to assist lawyers with allocation of aggregate settlements, alleviating the allocation problems at least to some extent. But third parties come at a price that not every settlement can justify.

\section{The Holdout Problem}

All-or-nothing settlements carry a risk of strategic holdouts. When a settlement includes a clause that conditions the deal on acceptance by every member of the group, a savvy client may withhold assent to extort additional money. An attorney who succumbs to the extortion and allocates additional money to holdout clients violates the lawyer's duty to the remaining clients.

Charles Silver and Lynn Baker explain that a unanimous consent requirement, by enabling strategic holdouts, creates a risk of misallocation and gives disproportionate bargaining power to the least deserving claimants:

Critically, this requirement enables a single plaintiff to block an allencompassing group deal unless he or she receives a disproportionately large share of the available funds. A strategic plaintiff with little at stake in a lawsuit, such as a person who was exposed to asbestos but has no disease, can therefore make a credible threat to veto a desirable group deal unless paid a disproportionately large amount. Because large-claim plaintiffs, such as mesothelioma victims, usually have the most urgent need for money as well as the most to lose (in terms of both time and money) by trying their cases, they occupy a weak bargaining position vis-à-vis small-claim plaintiffs and may have difficulty resisting a small-claim plaintiff's extortion efforts. The Rule's nonwaivable unanimity requirement creates an intra-group bargaining game in which the most deserving plaintiffs may often be at the mercy of the least deserving. ${ }^{178}$

177. See supra Part II.F.

178. Charles Silver \& Lynn A. Baker, Mass Lawsuits and the Aggregate Settlement Rule, 32 WAKE FoREST L. REV. 733, 767 (1997) [hereinafter Silver \& Baker, Aggregate Settlement Rule]; see also Kerrie M. Brophy, Consent Waivers in Non-Class Aggregate Settlements: Respecting Risk Preference in a Transactional Adjudication Model, 22 GeO. J. Legal ETHICS 677, 680 (2009) ("Premium holdouts are one of the most concerning unintended consequences of the unanimity 
Strategic holdouts, unless steadfastly resisted, lead to problems of misallocation and disloyalty. ${ }^{179}$ In fen-phen settlements and in the Phillips chemical plant settlement, lawyers were accused of using some of the available settlement funds to increase offers for clients who objected to their initial allocations. Strategies to minimize the risk of holdouts, such as the mandatory withdrawal clause in the Vioxx settlement, may ensure participation at too great an ethical cost. ${ }^{180}$

Silver and Baker present the holdout concern as a problem with the aggregate settlement rule. ${ }^{181}$ They describe the aggregate settlement rule, which requires clients' informed consent to an aggregate settlement after disclosure, ${ }^{182}$ as a rule requiring "unanimous consent." from their assumption that aggregate settlements are, or ought to be, fully inclusive. ${ }^{184}$ Because they see global resolution as the ultimate objective, they treat the holdout problem as a reason to permit advance consent to aggregate settlements. ${ }^{185}$ The American Law Institute's Principles of the Law of Aggregate Litigation, proposing legal reforms that would permit lawyers to obtain their clients' advance consent to aggregate settlements, ${ }^{186}$ picks up on Silver and Baker's reasoning that the informed consent requirement gives individual clients veto power and thus enables strategic holdouts:

Current law prohibits waiving individual-claimant settlement decisionmaking, thereby empowering individual claimants to exercise unfair control over a proposed settlement and to demand premiums in exchange for approval. ... Subsection (b) takes the view that giving

requirement in non-class aggregate settlement groups.").

179. It bears emphasizing that claimants decline to settle for many reasons. Claimants' litigation objectives and risk tolerance vary, as does the value they place on their own claims. Not every claimant who declines a settlement offer is a "holdout" in the strategic sense described here. In this section, "the holdout problem" refers specifically to the risk that claimants may threaten to withhold consent as a means to gain a disproportionate share of settlement funds. Both types of nonsettling claimants, however, are problematic in the context of all-or-nothing settlements.

180. See supra text accompanying notes $126-51$.

181. Silver \& Baker, Aggregate Settlement Rule, supra note 178, at 767-68; see also Charles Silver \& Lynn Baker, I Cut, You Choose: The Role of Plaintiffs' Counsel in Allocating Settlement Proceeds, 84 VA. L. Rev. 1465, 1520, 1532 (1998) [hereinafter Silver \& Baker, I Cut, You Choose].

182. MOdEl RULES OF PROF'L CONDUCT R. 1.8(g) (2009).

183. Silver \& Baker, Aggregate Settlement Rule, supra note 178, at 767; see also Silver \& Baker, I Cut, You Choose, supra note 181, at 1469.

184. See Silver \& Baker, Aggregate Settlement Rule, supra note 178, at 767-68.

185. See id. at 768-70. Advance consent to aggregate settlements is impermissible under current interpretations of the aggregate settlement rule. See Hayes v. Eagle-Picher Indus., Inc., 513 F.2d 892, 894 (10th Cir. 1975); Knisley v. City of Jacksonville, 497 N.E.2d 883, 886-89 (Ill. App. Ct. 1986); Tax Authority, Inc. v. Jackson Hewitt, Inc., 898 A.2d 512, 522 (N.J. 2006).

186. AgGREGATE LitigAtion, supra note 5, § 3.17(b)-(e). 
veto power to individual claimants (as opposed to collectively) is not necessary to ensure the fairness of aggregate settlements.

Properly understood, the aggregate settlement rule is not a rule of unanimous consent. ${ }^{188}$ It is a rule that insists that no client may be bound by an aggregate settlement, unless that client gives informed consent after full disclosure of the terms of the deal. ${ }^{189}$ In an all-or-nothing settlement, this informed consent requirement functions as a unanimity rule. ${ }^{190}$ But in an aggregate settlement that does not require every client's participation, the informed consent requirement does not function as a unanimity rule. ${ }^{191}$ The mistake of referring to the aggregate settlement rule as a unanimity requirement, or as a rule that gives each client "veto power" over the settlement, follows from the unwarranted assumption that aggregate settlements must be all-or-nothing deals. ${ }^{192}$

Thus, the holdout problem should be understood not as a problem with the aggregate settlement rule's requirement of informed consent, but rather as a problem with deals that are structured to require full participation. An aggregate settlement presents a risk of strategic holdouts only if the settlement is conditioned upon acceptance by all, or nearly all, of the claimants. A mass settlement with, say, a $90 \%$ walkaway clause rather than an all-or-nothing clause entails no realistic holdout risk because no individual client has the power to derail the deal.

Turning to the lawyer's role when dealing with strategic holdouts, one might argue that holdouts would not present a problem if lawyers had sufficient backbone to resist clients' unreasonable demands. On this view, a lawyer faced with a client who tries to extort additional money from an evenly allocated aggregate settlement should refuse to succumb and should simply tell the client that the client is entitled to reject the settlement if the client is unsatisfied. But that view, while probably a correct account of how a lawyer ought to handle the strategic holdout client, misses the structural point. It is much easier for a lawyer to tell an unsatisfied client simply to reject a settlement when that rejection will not ruin the entire deal for the lawyer and all of the other clients.

187. Id. $\S 3.17 \mathrm{cmt} . \mathrm{b}$.

188. Erichson, supra note 167 , at 1805.

189. Id.

190. Id. at $1805-06$

191. Id. at 1806.

192. See id. at $1805-06$. 


\section{The Slush Fund Problem}

When a defendant offers an appealing lump-sum settlement to resolve a group of claims, the lawyer representing the claimants naturally tries to get the deal done. Not only does the lawyer have an interest in obtaining fees from the settlement, but as a loyal advocate, the lawyer wishes to get the benefit of the deal for all of the clients. For a deal conditioned on full participation, the lawyer needs every client's consent. If some clients strategically hold out for more money or are simply dissatisfied with their settlement amounts, the deal is at risk.

One plausible - though unethical-response to this risk is to reserve some funds from the total settlement amount so that individual offers can be sweetened as necessary to secure each client's participation. Suppose a defendant offers $\$ 10$ million to settle 100 claims, conditioned on full participation, leaving the allocation to the plaintiffs' lawyer. The plaintiffs' lawyer, worried about whether every client will say yes, might devise an allocation of 100 individual settlement amounts totaling only $\$ 8$ million, keeping \$2 million in reserve. The lawyer might then meet with each client to convey the settlement amount based on the lawyer's allocation. If a client says yes, the lawyer gets the client's signature. If a client says no, then the lawyer increases the offer-or, more deceptively, tells the client that the defendant has increased its offer-until the client says yes.

The most egregious example of an aggregate settlement slush fund is the Kentucky fen-phen settlement. There, the lawyers were convicted not merely of keeping money in reserve to ensure full participation, but of taking additional money for themselves out of the funds that had been set aside. ${ }^{193}$ In other settlements, law firms were accused of reserving funds from initial allocations in order to increase individual amounts as necessary to gain every client's participation. ${ }^{194}$

Even if lawyers do not use the excess funds to overpay themselves, slush funds are problematic. If a defendant offers a lump sum amount to resolve a group of claims, and the plaintiffs' lawyer or a mediator determines how to allocate that amount among the individual clients, the offers conveyed to the clients should add up to the total offered by the defendant. If the lawyer favors certain clients over others for reasons other than the value of the claims, then the lawyer is succumbing to the

193. See supra Part II.A.

194. See supra Part II.B-F. 
client-client conflict of interest inherent in the aggregate settlement. ${ }^{195}$ That conflict of interest is subject to consent only to the extent the lawyer reasonably believes that she can give loyal representation to each of the clients. $^{196}$

Moreover, the slush fund approach to obtaining client consent almost inevitably involves deception. Imagine a lawyer telling each client honestly that a portion of the defendant's lump-sum offer has been reserved to increase the dollar amounts for clients who decline the initial allocation! In the fen-phen settlements involving the Napoli firm, the Locks firm, and the Kentucky lawyers, the plaintiffs' lawyers were accused of leading their clients to believe that the defendant had offered certain amounts, when in fact the defendant had made a lump-sum offer and left the allocation to the plaintiffs' lawyers. Misleading clients about the nature of the offers and the source of the allocation violates not only the general rule against deceptive conduct, ${ }^{197}$ but also the requirement of disclosure and informed consent for aggregate settlements. ${ }^{198}$

In sum, a slush fund is one possible response by plaintiffs' lawyers to the pressure created by the need to obtain every client's consent to a settlement. Such reserve funds may tempt lawyers to misallocate funds for their own benefit by favoring some clients over others. Worse, if a reserve fund results in a remainder after clients have been satisfied, it may tempt a lawyer to misappropriate client funds. Even if lawyers take no more than their legitimate fee, the slush fund approach involves deception of clients and a client-client conflict.

\section{E. The Loyalty Problem}

If a settlement is conditioned on participation by all of a lawyer's clients, the lawyer faces a difficult situation when individual clients decline the settlement. Some lawyers have withdrawn from representing non-assenting clients, raising ethical concerns about attorney loyalty. ${ }^{199}$ Numerous cases have held that a client's rejection of a settlement

195. See Model Rules of Prof'L Conduct R. 1.7(a)(2), 1.8(g) (2009).

196. See MOdEL RULES OF PROF'L CONDUCT R. 1.7(b) (2009).

197. See Model Rules of Prof'L CONDUCt R. 8.4(c) (2009).

198. See Model Rules of Prof'L Conduct R. 1.8(g) (2009).

199. In some cases, lawyers' motions to withdraw from representing non-settling clients apparently have been handled without much attention to the ethical issues involved in such withdrawal. See, e.g., Tax Authority, Inc. v. Jackson Hewitt, Inc., 898 A.2d 512, 516 (N.J. 2006) (noting that the trial court granted the plaintiffs' attorney's motion "for leave to withdraw as counsel for parties declining the agreement due to a conflict between those plaintiffs who had signed the settlement agreement and those who had not"). 
recommended by the lawyer does not constitute good cause for a lawyer to terminate the representation. ${ }^{200}$ Moreover, under the circumstances of an aggregate settlement offer, a lawyer's threat to withdraw has a coercive aspect that impinges on the client's unquestioned right to decide whether to accept or reject a settlement. ${ }^{201}$

The issue of loyalty in aggregate settlements came to the fore in the controversy over the Vioxx settlement. ${ }^{202}$ That settlement required that any participating lawyer recommend the settlement to all of her clients ${ }^{203}$ and withdraw from representing any client who declined the settlement. ${ }^{204}$ These controversial provisions, included because of the defendant's insistence that the deal be all-inclusive as to each participating lawyer, put enormous pressure on clients to accept the settlement.

From the perspective of a lawyer who has been given an all-ornothing settlement offer, the conflict of interest between would-be settling and non-settling clients is palpable. In the face of such a conflict, a lawyer might want to conclude that withdrawal is not only a reasonable course of action, but ethically necessary. ${ }^{205}$ If withdrawal

200. See DeFlumer v. LeSchack \& Grodensky, P.C., No. 99-CV-1650 (NAM/DRH), 2000 WL 654608 , at *1 (N.D.N.Y. May 19, 2000) ("The mere fact that an attorney and client may disagree over a proposed settlement will not establish good cause for withdrawal of representation."); Marrero v. Christiano, 575 F. Supp. 837, 839 (S.D.N.Y. 1983) ("[T] he refusal of a client to accept a settlement offer is not good and sufficient cause for the withdrawal of the attorney."); Tsavaris v. Tsavaris, 244 So.2d 450, 452-53 (Fla. Dist. Ct. App. 1971); In re Busby, 616 N.Y.S.2d 755, 756 (N.Y. App. Div. 1994); Michael D. Tully Co. v. Dollney, 537 N.E.2d 242, 245 (Ohio Ct. App. 1987); ABA-BNA LAWYER'S MANUAL ON PROFESSIONAL CONDUCT 31:1107 (Ellen J. Benett et al. ed., ABA/BNA 2004) (citing Hobart v. Decker (In re Falco), 233 Cal. Rptr. 807, 815 (Cal. Ct. App. 1987)); see also Hobart v. Decker, 233 Cal. Rptr. 807, 815-16 (Cal. Ct. App. 1987) (rejecting lawyer's quantum meruit fee application on grounds that client's rejection of settlement was not good cause for withdrawal); May v. Seibert, 264 S.E.2d 643, 646 (W. Va. 1980) (same).

201. Model RULES OF PROF'L CONDUCT R. 1.2(a) (2009).

202. See supra Part II.E.

203. Vioxx Settlement Agreement, supra note 127, § 1.2.8.1.

204. Id. § 1.2.8.2.

205. Indeed, under some circumstances involving settling and non-settling clients, withdrawal may be mandatory. See N.C. State Bar, Ethics Op. RPC 251 (1997) (Where a lawyer represents four personal injury claimants and the insurance coverage cannot compensate all four clients fully, the lawyer may have to withdraw from all of the clients if they do not agree on a settlement: "The lawyer must withdraw from the representation of all of the claimants if the lawyer is placed in the role of advocate for one or more of the claimants against the other claimants. The lawyer must also withdraw from the representation if one or more of the claimants do not agree to accept the settlement offer. If the lawyer must withdraw, the lawyer may continue to represent one or more of the claimants only with the consent of the claimants whose cases the lawyer relinquishes."); Tenn. Bd. Prof'l Resp., Ethics Op. 95-F-136 (1995) (Where an attorney represents both a personal injury claimant and the client's health insurer with a subrogation interest, "[a]t the time of the initial contact by the health insurance provider, the attorney should advise the health insurance provider both orally and in writing that if both clients do not agree on the proposed settlement, then the lawyer may not continue his multiple employment and must withdraw from representing the health 
were ethically required, however, it is not clear that the lawyer could drop the non-settling clients while continuing to represent the settling clients. Rather, it may be that the lawyer would have to withdraw from all of the clients, absent consent. ${ }^{206}$ A lawyer may not drop one client like a "hot potato" in order to represent a more lucrative client. ${ }^{207}$ It is difficult to see any ethical justification for withdrawing from only those clients who decline a settlement offer, particularly given the law's insistence that the settlement decision belongs to the client. ${ }^{208}$

Lawyer loyalty issues may arise whenever a lawyer and client disagree about a settlement, but all-or-nothing settlements introduce loyalty issues in the most emphatic way. In an all-or-nothing settlement, the loyalty question is whether a lawyer can continue to represent certain clients after their rejection of a settlement threatens to kill an entire deal. Even more starkly, loyalty questions arise when withdrawal is contractually mandated, as in the Vioxx settlement. In that circumstance, the deal's all-or-nothing character is itself a function of a disloyalty requirement.

\section{F. The Informed Consent Problem}

Defendants' insistence on comprehensive settlements gives rise to special problems of informed consent. The decision to accept or reject a settlement belongs to clients, ${ }^{209}$ and aggregate settlements in particular require clients' informed consent after disclosure of the terms of the deal. The Rules of Professional Conduct spell out the requirement for aggregate settlements:

insurer.”); RESTATEMENT (THIRD) LAW GOVERNING LAWYERS $§ 128$ cmt. d(i), illus. 2 (2000) (In a two-client aggregate settlement with insufficient coverage for both claimants, "[i]f one client wishes to accept and the other wishes to reject the proposed settlement, Lawyer may continue to represent both A and B only after a renewal of informed consent by each.").

206. N.C. State Bar, Ethics Op. RPC 251 (1997).

207. See, e.g., Picker Int'l, Inc. v. Varian Assocs., Inc., 869 F.2d 578, 584 (Fed. Cir. 1989); Santacroce v. Neff, 134 F. Supp. 2d 366, 367 (D.N.J. 2001) ("The 'Hot Potato Doctrine' has evolved to prevent attorneys from dropping one client like a 'hot potato' to avoid conflict with another, more remunerative client.").

208. My point is not that conflicts between settling and non-settling clients require withdrawal. On the contrary, most conflicts of interest in mass settlements are consentable. Rather than require withdrawal whenever client choices diverge, the sounder approach in most cases is to address conflicts through the informed consent provisions of the aggregate settlement rule. My point here is simply that lawyers may not conveniently invoke the conflict of interest rules as a basis for dropping non-settling clients while continuing to represent those who accept a settlement.

209. See Model Rules of Prof’L CONDUCT R. 1.2(a) (2009). 
A lawyer who represents two or more clients shall not participate in making an aggregate settlement of the claims... unless each client gives informed consent, in a writing signed by the client. The lawyer's disclosure shall include the existence and nature of all the claims or pleas involved and of the participation of each person in the settlement. $^{210}$

In theory, there is no inconsistency between all-or-nothing settlements and the requirement of informed consent. Compliance with the aggregate settlement rule simply requires that the lawyer disclose the terms of the deal and give each client the opportunity to accept or reject the settlement. A lawyer who represents a group of claimants could inform each client that the defendant has agreed to settle on condition that the settlement include every claimant in the group. The lawyer could explain the terms of the deal to each client, showing how much the client would receive and how that amount fits into the overall allocation.

The problem is that an all-or-nothing settlement puts enormous pressure on the plaintiffs' lawyer to obtain a "yes" from every client. The lawyer's duty to provide a straightforward disclosure bumps up against the hard reality that a non-settling client may ruin the deal for the entire group and, as a result, may deny the lawyer a hefty fee. The plaintiffs' lawyer understands the risk of strategic hold outs as well as the more general risk of non-settling claimants. A lawyer seeking to ensure full participation thus may be inclined to provide less-than-completeand-honest disclosures about the terms of the overall deal. In the cases involving the Leeds Morelli settlements, ${ }^{211}$ clients accused the law firm of pressuring the clients to consent and failing to disclose the full extent of the law firm's relationship with the defendants. ${ }^{212}$ In the cases involving the Kentucky fen-phen settlement, ${ }^{213}$ the Napoli fen-phen settlement, ${ }^{214}$ and the Phillips chemical plant settlement, ${ }^{215}$ plaintiffs similarly accused the lawyers of pressuring clients to accept the deal and failing to make proper disclosures about the overall settlement. ${ }^{216}$

\footnotetext{
210. Model Rules of Prof'L CONDUCt R. 1.8(g) (2009).

211. See supra Part II.D.

212. See Juri, supra note 105 ("[The Leeds Morelli clients] said they were browbeaten into accepting settlements" that their law firm negotiated with Prudential.); Neil, supra note 105 ("These plaintiffs now claim they were pressured into settling without knowing about the possible $\$ 5$ million payment....").

213. See supra Part II.A.

214. See supra Part II.B.

215. See supra Part II.F.

216. See also Goffney v. O'Quinn, No. 01-02-00192-CV, 2004 WL 2415067, at **8-9 (Tex. App. Oct. 28, 2004) (involving claims that lawyer pressured clients to accept all-or-nothing aggregate settlement of claims of toxic chemical exposure at Brio work site).
} 
Alternatively, there is a risk that lawyers seeking to ensure full participation may give each client little genuine choice about whether to say yes. The main criticism of the Vioxx settlement ${ }^{217}$ was not that there were incomplete or misleading disclosures; indeed, it was an uncommonly transparent deal. Rather, the criticism was that the clients' informed consent was meaningless because they essentially had no real choice. When a lawyer tells a client that the lawyer will withdraw if the client declines the settlement, few clients can say no.

The challenge of obtaining universal consent to settlements has led to proposals to abandon the informed consent requirement in mass aggregate settlements or to permit lawyers to obtain their clients' consent in advance. Most prominently, the Principles of the Law of Aggregate Litigation includes a detailed proposal to allow clients to bind themselves in advance to an aggregate settlement based on a supermajority vote of the client group. ${ }^{218}$ Cases had uniformly held that advance consent was impermissible under the aggregate settlement rule; client consent to aggregate settlements must be based on disclosure of the actual terms of the deal. ${ }^{219}$ The ALI proposal for statutory reform would overrule these cases. By permitting clients to agree in advance to be bound by a yet-tobe-negotiated deal, the proposal would bypass the back-end problem of informed consent. Rather than truly eliminating the problem of informed consent, however, the proposal frontloads the problem. It raises questions about whether clients, at the time they sign initial retainer agreements, can understand the implications of waiving their right to individually decide whether to settle. ${ }^{220}$ It also raises questions about

217. See supra Part II.E.

218. AgGREgate Litigation, supra note $5, \S 3.17(\mathrm{~b})$.

219. See Hayes v. Eagle-Picher Indus., Inc., 513 F.2d 892, 894 (10th Cir. 1975) ("An agreement ... which allows a case to be settled contrary to the wishes of the client and without his approving the terms of the settlement is opposed to the basic fundamentals of the attorney-client relationship."); Knisley v. City of Jacksonville, 497 N.E.2d 883, 887 (Ill. App. Ct. 1986) (“[I]t is essential that the final settlement be subject to the client's ratification particularly in a non-class action case ....”); Tax Authority, Inc. v. Jackson Hewitt, Inc., 898 A.2d 512, 522 (N.J. 2006) ("Before a client may be bound by a settlement, he or she must have knowledge of the terms of the settlement and agree to them."); ABA Comm. on Ethics and Prof'l Responsibility, Formal Op. 06438 (2006); Ass'n of the Bar of the City of New York, Formal Ethics Op. 2009-06 (2009).

220. See Nancy J. Moore, The American Law Institute's Draft Proposal to Bypass the Aggregate Settlement Rule: Do Mass Tort Clients Need (or Want) Group Decision Making?, 57 DEPAUL L. REV. 395, 419-20 (2008) ("It is difficult to imagine that attorneys could provide disclosures at the outset of the representations that would be adequate for unsophisticated mass tort clients to reasonably understand the material risks of such waivers."). As one ethics committee recently put it,

' $[I]$ nformed consent' to an advance waiver is virtually a contradiction in terms. ... In most cases, at the outset of an engagement, and indeed at any point prior to an actual settlement negotiation, it may be difficult, if not impossible, for a lawyer to possess, and therefore disclose, enough information to enable the client to understand the risks of 
whether, if such advance consent were permitted, clients would have realistic options to obtain legal representation without giving such advance consent. Finally, it raises questions about whether such advance consent, even if truly informed and truly consensual, is fundamentally inconsistent with the lawyer's role in representing clients in nonclass disputes. These are difficult questions beyond the scope of this Article. ${ }^{21}$ For present purposes, the point is that defendants' insistence on all-or-nothing settlements puts pressure on the ethical requirement of informed consent. That pressure leads not only to cases of incomplete or misleading disclosures, but also to efforts to dilute the informed consent requirement by disconnecting it from the actual terms of a settlement.

\section{G. The Collusion Problem}

All-or-nothing settlements align certain interests of plaintiffs' counsel with the interests of the defendant, potentially to the disadvantage of individual plaintiffs. A lawyer who represents numerous plaintiffs stands to benefit greatly by completing a deal for the resolution of all of the claims.

The risk of collusion is now well recognized in settlement class actions. As the Amchem and Ortiz class actions were making their way up to the Supreme Court, several observers pointed out that class counsel faced strong incentives to acquiesce in defendants' demands. ${ }^{222}$ John Coffee described the "reverse auction" problem: "settlement class actions permit defendants to run a reverse auction, seeking the lowest bidder from a large population of plaintiffs' attorneys." ${ }^{223}$ Because the terms of a settlement class action are negotiated before class certification is granted, a would-be class lawyer who bargains too hard risks losing the opportunity to represent the settlement class, while a would-be class lawyer who agrees to settle on terms favorable to the defendant gets the chance to represent the class and earn substantial fees. ${ }^{224}$ Settlement

waiving the right to approve a settlement following disclosure of all material facts and terms.

Ass'n of the Bar of the City of New York, Formal Ethics Op. 2009-06 (2009).

221. These problems are addressed in Erichson \& Zipursky, supra note 2.

222. See John C. Coffee, Jr., Class Wars: The Dilemma of the Mass Tort Class Action, 95 Colum. L. Rev. 1343, 1367-84 (1995) [hereinafter Coffee, Class Wars]; Susan P. Koniak, Feasting While the Widow Weeps: Georgine v. Amchem Products, Inc., 80 CoRnEll L. REV. 1045, 1051-85 (1995); Brian Wolfman \& Alan B. Morrison, Representing the Unrepresented in Class Actions Seeking Monetary Relief, 71 N.Y.U. L. REV. 439, 447-76 (1996).

223. John C. Coffee, Jr., Rule of Law: The Corruption of the Class Action, Wall St. J., Sept. 7, 1994, at A15; see also Coffee, Class Wars, supra note 222, at 1379.

224. Howard M. Erichson, Mass Tort Litigation and Inquisitorial Justice, 87 GEO. L.J. 1983, 
class actions also present a risk of collusive side deals that benefit a lawyer's nonclass clients at the expense of class members, as a defendant may be willing to pay a premium on individual claims in order to secure class counsel's agreement to a cheaper settlement of the class claims. ${ }^{225}$

To a large extent, nonclass settlements do not raise the same concerns about collusion as settlement class actions. A nonclass settlement differs from a settlement class action, in which a lawyer who successfully strikes a deal with the defendant gets the benefit of seeking class certification and settlement approval as the presumptive class counsel. In a nonclass aggregate settlement, the reverse auction risk does not exist, as each lawyer already represents a roster of clients and the defendant has no power to offer the franchise to the lowest bidder.

Nonetheless, nonclass aggregate settlements present a risk of collusion, especially in all-or-nothing deals. ${ }^{226}$ In the Leeds Morelli settlements of its clients' employment claims, ${ }^{227}$ the law firm struck deals with defendants in which the firm agreed to accept substantial payments and to be retained by the defendants as a paid consultant. At the core of the disputes over these settlements is the concern that the firm's interests became aligned with those of the employer defendants, potentially at the expense of its own clients.

Similarly, an all-or-nothing settlement of claims involving DuPont's fungicide Benlate resulted in disciplinary sanctions against the plaintiffs' lawyers amidst charges of collusion. ${ }^{228}$ The plaintiffs' law firm represented twenty clients with claims of property damage. DuPont agreed to settle the claims for $\$ 59$ million conditioned upon (1) the participation of all twenty clients, (2) the law firm's agreement not to represent the current clients or others in further Benlate proceedings, and

2002 (1999).

225. Id. See also Coffee, Class Wars, supra note 222, at 1373-74 (“[B]oth sides have an incentive to trade a settlement of the plaintiffs' attorney's entire inventory (on terms favorable to the attorney) for a global settlement in a class action of all future claims (on terms favorable to the defendants)."); Koniak, supra note 222, at 1064 (arguing that class counsel in Amchem settled over 14,000 asbestos cases outside the class framework while they were negotiating the Gerogine class action).

226. See Roger Cramton, Lawyer Ethics on the Lunar Landscape of Asbestos Litigation, 31 PEPP. L. REV. 175, 194 (2003) ("The dangers of self-interested, and even collusive, behavior by plaintiff lawyers have been recognized as a serious problem in class action cases. Consolidated cases that involve hundreds or thousands of claimants involve an even greater problem because all of the protections of class actions have been eliminated ...."); see also Burch, supra note 166, at 11 ("Settlements advantage those most familiar with the process, the repeat players: plaintiffs' attorneys and defense attorneys as well as judges.").

227. See supra Part II.D.

228. Fla. Bar v. Rodriguez, 959 So.2d 150, 153, 161-62 (Fla. 2007); David D. Dodge, Secret Settlement Terms Can Spell Trouble, ARIZ. ATT'Y, Sept. 2008, at 8, 8. 
(3) the law firm's agreement to be retained by DuPont after the settlement was completed; DuPont would pay the plaintiffs' law firm directly. ${ }^{229}$ The lawyers did not disclose these terms to their clients or to the court. ${ }^{230}$ A client eventually learned of the deal and reported the matter to the Florida Bar. ${ }^{231}$ One of the lawyers was disbarred, two were suspended, one received a public reprimand, and all four were ordered to disgorge their fees. ${ }^{232}$ The Florida Supreme Court, finding numerous ethical violations, emphasized the extent to which the lawyers' loyalty to their clients was compromised by their relationship with the defendant: "He became an agent for DuPont while still representing his Benlate clients against DuPont." 233

Even in the absence of direct payments from defendants or consultancy agreements, all-or-nothing aggregate settlements present a risk that plaintiffs' lawyers will advance the interests they share with defendants rather than maximizing the interests of their clients. If a lawyer can negotiate a reasonably lucrative deal that resolves the claims of the lawyer's entire roster of relevant clients, then the lawyer takes a hefty fee and moves on to new business. Plaintiffs' lawyers thus share defendants' interest in closing a deal and getting all of the plaintiffs on board.

\section{CONCLUSION}

This Article has pointed out the trouble with all-or-nothing settlements both by telling stories of mass settlements gone awry and by cataloguing seven types of problems that are generated or exacerbated by all-or-nothing deals.

First, all-or-nothing settlements create both client-client and lawyerclient conflicts of interest, and the requirement of full participation exacerbates conflicts that exist in other aggregate settlements. Second, they introduce problems concerning the allocation of settlement funds, including incentives to misallocate. Third, they create a risk of strategic holdouts, as savvy clients may attempt to extort additional money by withholding their consent to the deal. Fourth, they create an incentive for

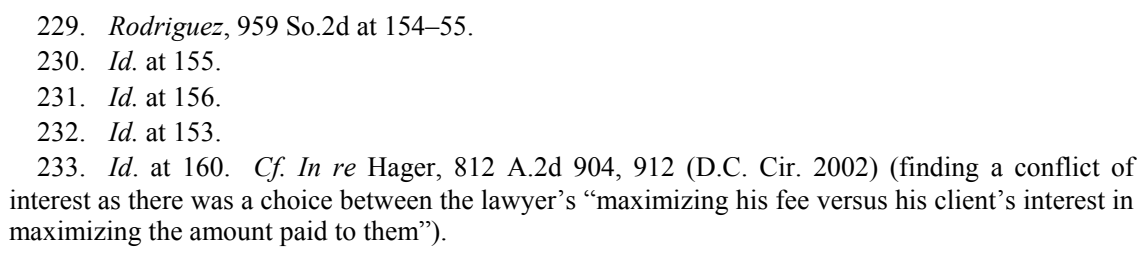


lawyers to keep settlement money in reserve as a slush fund to ensure full participation, leading to problems of misallocation and client deception. Fifth, they create or exacerbate a loyalty problem by pressuring lawyers to withdraw from representing non-settling clients. Sixth, they create special problems concerning clients' informed consent to aggregate settlements. And seventh, they introduce a risk of collusion as the interest of plaintiffs' counsel aligns with the defendant's interest in getting every plaintiff to sign on to the deal. In sum, settlements that insist upon total participation place claimants' counsel in the ethically precarious position of facing unavoidable conflicts of interest and powerful incentives to deceive and abuse some clients in order to get the deal done. Because of these problems, lawyers generally should resist demands for all-or-nothing settlement terms, courts should refrain from pressuring parties to reach absolute closure, and ethics committees and rule-makers should resist demands to alter rules in the service of all-ornothing settlements.

The fact remains, however, that mass aggregate settlements are an essential component in the resolution of widespread disputes, and peace is a key objective of most defendants in negotiating mass settlements. What is the alternative to all-or-nothing settlements? In mass disputes, the alternative to all-or-nothing settlements is not individual trials and individual settlements of every claim, which in most cases would be foolishly inefficient. Rather, the realistic alternatives are nonclass mostor-nothing settlements or binding class settlements in certified class actions.

One alternative is what I call most-or-nothing settlements. Many disputes are successfully resolved without all-or-nothing terms but rather with settlements that contain walkaway clauses requiring 85,90 , or $95 \%$ participation. Most-or-nothing settlements do not guarantee absolute peace in the sense of promising that every client is on board. ${ }^{234}$ Inasmuch as defendants value comprehensive peace, it is fair to presume in many cases that the failure to provide such a guarantee of total peace means that claimants lose some of the value in the settlement. ${ }^{235}$

234. Most-or-nothing settlements also do not guarantee the removal of a particular plaintiffs' law firm from the litigation, but in any event such a guarantee would run afoul of the ethical prohibition on restricting a lawyer's practice. See Model Rules OF PROF’L CONDUCT R. 5.6(b) (2009) (“A lawyer shall not participate in offering or making an agreement in which a restriction on the lawyer's right to practice is part of the settlement of a client controversy.").

235. See Richard Nagareda, Public and Private Law Perspectives: Transcript of Professor Richard Nagareda, 37 Sw. U. L. REV. 659, 661 (2008) ("Why have we in the law bothered thinking for so long about how to legitimize these sorts of settlement arrangements? I submit that the driving intuition is that they have a considerable potential ... to be value-generating transactions for both 
Although they do not guarantee total peace, most-or-nothing settlements provide substantial finality. A reasonable settlement may well attract the participation of all of the eligible claimants even without an all-ornothing clause. Overwhelmingly, clients follow their lawyer's advice on whether to accept a settlement. Without an all-or-nothing clause, there is nothing to be gained by holding out, as no individual client can hold the deal hostage. Even if a few clients decline the settlement, the defendant can quantify the remaining risk and largely put the litigation behind it.

Mass settlements with most-or-nothing provisions raise far fewer ethical concerns than those that require unanimity. Although they involve certain conflicts of interest, introduce allocation challenges, and require informed consent after full disclosure, they do not create the same pressure to obtain a yes from every client. Most-or-nothing settlements therefore do not present the same holdout risk and are unlikely to lead plaintiffs' lawyers to use slush funds to ensure participation. Nor do they present as strong a risk of collusion or disloyalty. Moreover, because defendants place value on ensuring that mass settlements draw the participation of strong claimants as well as weaker ones, most-or-nothing settlements should be less likely than allor-nothing settlements to undervalue the strongest claims. Settlements with genuine walkaway clauses guarantee defendants sufficient finality to make settlement worthwhile but, unlike all-or-nothing settlements and their functional equivalents, they leave an ethical safety valve so that lawyers need not pressure or lure every client into submission.

Another alternative, of course, is the class action. If a defendant seeks to settle with an entire claimant group, the defendant may try to negotiate a settlement class action or, if a litigation class has been certified, the defendant may negotiate a settlement of the class action. In place of individual settlement autonomy, class actions substitute procedural protections including class certification, appointment of class counsel, judicial control of fees, and judicial approval of settlement after notice and a hearing. Like most-or-nothing settlements, settlement class actions generally do not guarantee total peace-money damages class actions under Federal Rule of Civil Procedure 23(b)(3) permit opt-outsbut they do provide significant finality and allow defendants to constrain and quantify the remaining risk. The great limitation of class actions as

sides of the litigation as well as for society as a whole. That is why it is worth the legal system's time, and our time, to sort out these arrangements. Value-generation - the capacity of these deals to create wealth that would not otherwise exist_-is directly related to the peace that the deal actually delivers and, hence, to the coercive power that it exercises."). 
peace-creators is that many mass disputes are unsuitable for class certification because of the predominance of individual issues.

Even in disputes that do not lend themselves to class certification, defendants may demand greater finality than can be guaranteed by a most-or-nothing nonclass settlement. These are the situations in which the call for all-or-nothing deals is strongest. In appropriate cases, nonclass settlements conditioned on total peace may generate significant value while creating only a manageable level of ethical tension, but as a general matter, such settlements ought not be exalted as the desired endgame of mass disputes. The value of conditioning settlements on full participation must be weighed against the trouble caused by such insistence. 